\title{
OPEN Water budgeting in conservation agriculture-based sub-surface drip irrigation in tropical maize using HYDRUS-2D in South Asia
}

\author{
Kiranmoy Patra更, C. M. Parihar ${ }^{1,8}$, H. S. Nayak ${ }^{1}$, Biswajit Rana ${ }^{1}$, V. K. Singh ${ }^{1}$, S. L. Jat ${ }^{2}$,
} Sanjeev Panwar ${ }^{3}$, M. D. Parihar ${ }^{4}$, L. K. Singh ${ }^{5}$, H. S. Sidhu ${ }^{5}$, B. Gerard ${ }^{6} \&$ M. L. Jat ${ }^{7 凶}$

In water scarce regions of South Asia, diversification of rice with maize is being advocated towards sustainability of cereal-based cropping systems. Adoption of innovative agronomic management practices, i.e., conservation agriculture (CA) and sub-surface drip irrigation (SSDI) are considered as key strategies for much needed interventions to address the challenges of water scarcity under projected climate change. Benefits from CA and SSDI concerning water economy are well-established, however, information about their complementarity and water budgeting in cereal-based systems are lacking. A field study was conducted with process-based model (HYDRUS-2D) to understand water transport, root water uptake and components of soil water balance in maize grown in rotation with wheat after five years of continuous adoption of conservation agriculture. In this study, altogether eight treatments comprising of 6 CA + treatments (CA coupled with SSDI); permanent beds using sub-surface drip (PB-SSD) with (WR) and without (WOR) crop residue at different $\mathrm{N}$ rates, 0, 120 and $150 \mathrm{~kg} \mathrm{~N} \mathrm{ha}^{-1}$ were compared with CA (PB using furrow irrigation-FI with crop residue-120 $\mathrm{kg} \mathrm{N} \mathrm{ha}^{-1}$ ) and conventional tillage practices (CT) (CT using FI without crop residue- $120 \mathrm{~kg} \mathrm{~N} \mathrm{ha}^{-1}$ ). Results showed that the model could simulate the daily changes in profile soil water content with reasonable accuracy in all the treatments. Simulated soil water balance indicated higher cumulative root water uptake (CRWU), lower cumulative evaporation (CE) and higher soil water retention in CA+ (PB-SSD+ crop residue at 150 and $120 \mathrm{~kg} \mathrm{~N} \mathrm{ha}^{-1}$ ) than CA and CT plots. Hydrus-2D model efficiency $>0, \mathrm{RMSE}$ between $0.009-0.026$ and $\mathrm{R}^{2}$ value between $0.80-0.92$ at $P<0.01$ indicates that the model is performing efficiently. The mean evaporation from CA+ treatments was 10 and $36 \%$ less than CA and CT treatments, respectively. On average, CRWU under CA+treatments were $14-48 \%$ higher than $\mathrm{FI}$ treatments. The mean cumulative deep drainage in CA+ plots was 80-100 mm less than CA and CT plots. In CA+ based plots significantly higher biomass production and radiation use efficiency were observed with reduced water use than $C A$ and $C T$. Therefore, the study justifies the water-saving nature of $\mathrm{CA}+$, while maintaining higher productivity and meeting the transpiration demand of crops and halting unnecessary evaporation and deep drainage losses.

In South Asia, rice-wheat (RW) system (13.5 million ha) is the principal determinant of food and livelihood security for billions of people ${ }^{1,2}$. Conventional rice cultivation involves intensive tillage for puddling which incurs huge water loss, deteriorates soil physical health and is a main source of anthropogenic greenhouse gas emmision ${ }^{3}$. Since the early 1970s (Green Revolution era), there has been a steady decline in groundwater table in most of the RW system of North-West (NW) India ${ }^{4-6}$. The rate of decline between 1973 and 2001 was about $0.2 \mathrm{~m}_{\text {year }}{ }^{-1}$, which got hastened by five-fold $\left(1.0 \mathrm{~m} \mathrm{year}^{-1}\right)$ between 2000 and $2006^{5}$. Over-exploitation of the groundwater for rice production is the most likely cause and free electricity for irrigation favours the over withdrawal. In this context, alternate resource use efficient and productive maize production system must

\footnotetext{
${ }^{1}$ ICAR-Indian Agricultural Research Institute (IARI), New Delhi, India. ${ }^{2}$ ICAR-Indian Institute of Maize Research (IIMR), Unit Office, New Delhi, India. ${ }^{3}$ Indian Council of Agricultural Research (ICAR), New Delhi, India. ${ }^{4}$ ChouharyCharan Singh Haryana Agriculture University (CCSHAU), Hisar, India. ${ }^{5}$ Borlaug Institute for South Asia (BISA)-CIMMYT, Ludhiana, India. ${ }^{6}$ International Maize and Wheat Improvement Center (CIMMYT), El-Batan, Texcoco, Mexico. ${ }^{7}$ International Maize and Wheat Improvement Center (CIMMYT), New Delhi, India. ${ }^{8}$ These authors contributed equally: Kiranmoy Patra and C. M. Parihar. ${ }^{\circledR}$ email: pariharcm@gmail.com; m.jat@cgiar.org
} 
be developed and deployed for sustainable food security and protecting ground water resources ${ }^{7}$. Adoption of conservation agriculture (CA), i.e., zero tillage with residue retention and crop diversification had ensured higher productivity and improvement in soil physical health ${ }^{8,9}$. Diversification of rice with $\mathrm{C}_{4}$ crops like maize, i.e., maize-wheat system is emerging as a potential alternative to RW system in NW-India. Maize-wheat (MW) system is the third most important cropping system $(\sim 1.86 \mathrm{Mha})$ and has the potential to expand under the emerging water crisis in the Indo Gangetic Plains (IGP) ${ }^{10}$. MW system with CA-based practices has twin benefits of superior food and fodder supply as well as enhanced soil health and water productivity (WP $)^{11}$.

Adoption of micro-irrigation is a promising approach for irrigation water-saving relative to conventional irrigation, i.e., furrow irrigation (FI) $)^{5,12}$. Precise water management through drip irrigation has shown numerous benefits in terms of water savings, yield and nutrient use efficiency in horticulture and vegetable crops ${ }^{13}$. To address the water scarcity problem surface drip irrigation has been evaluated as a viable option for the cereals like maize ${ }^{12,14}$, rice ${ }^{15}$ and wheat ${ }^{16}$. However, the adoption of surface drip irrigation in cereal-based systems has remained a cumbersome process all the time, as the laterals get anchored during field operations both in conventional and CA systems. To deal with this bottleneck and for better farmers' acceptance of micro-irrigation in cereal-based systems, subsurface drip irrigation (SSDI) can be advised.

Compared to surface drip irrigation, SSDI restricts the evaporation losses from the soil surface, facilitates the delivery of water and nutrients directly to the root zone that leads to efficient water use, reduces weed emergence and labor cost and allows seeding with CA-based no-tillage practices ${ }^{17}$. Fertigation through drip irrigation system reduces $\mathrm{N}$ losses thereby enhancing the nutrient use efficiency ${ }^{18}$. Numerous studies have reported several benefits from CA and SSDI with respect to the water economy. Therefore, there is an excellent scope to design an efficient irrigation scheme by combining these two emerging and novel technologies viz, CA and SSDI in cereal systems of IGP. To advance further, precise information about the components of soil water balance (SWB) is required. The research was designed as informations about the interaction effect of CA and SSDI on water budgeting in a cereal-based system is rare.

Water budgeting can be done with a detailed field experiment, but requirement of instruments like lysimeter and the cost of the experimentation pose limitation to do so. Alternatively modelling the soil hydrological process with a process-based models can give insight about soil water budgeting. A detailed mathematical simulation can help to design a more efficient irrigation system by knowing the fate of applied irrigation in the soil profile. The soil hydrological process-based model Hydrus- $2 \mathrm{D}^{19}$ can be used to simulate the two-dimensional water movement using Richard's equation for unsaturated flow in different soil layers. Since the initial introduction of Hydrus, it has been effectively evaluated for $\mathrm{SWB}^{20}$, groundwater recharge ${ }^{21}$, and for root water uptake $\mathrm{e}^{22}$ in unsaturated soil. In earlier studies, a good agreement between observed and simulated values for SWB components had been reported ${ }^{7,23,24}$. Previous research based evidences showed that under drip irrigation, Hydrus-2D was successfully calibrated and validated for $\mathrm{SWB}^{25,26}$, crop root water uptake ${ }^{27,28}$, soil wetting pattern ${ }^{29,30}$, irrigation scheduling ${ }^{31,32}$ and to evaluate the nutrient transport and distribution pattern ${ }^{33,34}$. Aggarwal et al. ${ }^{23}$ compared the SWB in the scenario of CA and CT and found a very good agreement between observed and simulated values. Parihar et al. ${ }^{9}$ simulated soil water dynamics in maize crop and found that cumulative root water uptake (CRWU) was significantly higher in CA-based zero-till (ZT) plots compared to CT plots.

Although the superiority of $\mathrm{CA}^{+}$(CA coupled with SSDI) towards increased WP and resource use efficiency are being reported recently, globally the components of soil water balance has not been quantified in various $\mathrm{CA}+$-based practices. Consequently, for a better understanding of water dynamics in the soil-plant-atmosphere continuum, the present study was conducted during the 6th year of practicing CA-based SSDI (CA+), CA-based FI and CT with different $\mathrm{N}$ doses in maize crop. The main focus of this study was to calibrate and validate the Hydrus-2D model using an inverse modelling approach for simulation of SWB in salutations of three tired agronomic innovations ranging from $\mathrm{CT}$ to $\mathrm{CA}$ and $\mathrm{CA}+$ under different $\mathrm{N}$ levels. It was hypothesized that soil moisture content will be higher and less variable in the effective root zone under CA+ SSDI $\left(\mathrm{CA}^{+}\right)$practices as compared with furrow irrigated CA and CT.

\section{Results}

Fractional intercepted photosynthetically active radiation (fIPAR) and partition of actual evapotranspiration. During the initial crop phase (1-13 days of simulation; DOS) the fIPAR values were low (0.009-0.047) (Fig. 1). Maximum light interception by crop canopy was observed during 65 DOS (i.e., 72-Days after sowing) in all the treatments except those without N (received no N). During 65 DOS (72-Days after sowing), the highest fIPAR (0.98) was observed in the PBWR-SSD-N150 plots followed by PBWOR-SSD$\mathrm{N} 150$ (0.92). However, CT and CA plots with $120 \mathrm{~kg} \mathrm{~N} \mathrm{ha}^{-1}$ application had similar fIPAR throughout the simulation period. On average, adoption of SSDI improved the light interception by $16 \%$ over FI during the peak growth period. The fIPAR values were used for partitioning ETc into actual evaporation and actual transpiration. The estimated evaporation and transpiration using Hydrus-2D followed a similar pattern as that of actual evaporation and transpiration.

Model calibration and validation. The model was well calibrated with the optimized soil hydraulic parameters with $\mathrm{R}^{2}$ and RMSE values for all the treatments. The comparison between observed and simulated soil water content along with 1:1 line is depicted in Fig. 2. For all the treatments it was observed that the model over-predicts the moisture content. However, the coefficient of determination value for all treatments lies between 0.80 to 0.92 . This indicates that the model could appropriately describe the variation in the soil moisture content. The calculated RMSE value for all the treatments ranged between 0.009 (PBWOR-SSD-N0) to 0.026 (PBWR-SSD-N120). The positive values of ME indicate efficient performance of the model for the entire treatments understudy. Therefore, from the obtained values of the parameters viz, $\mathrm{R}^{2}$, RMSE, ME, it can be concluded 


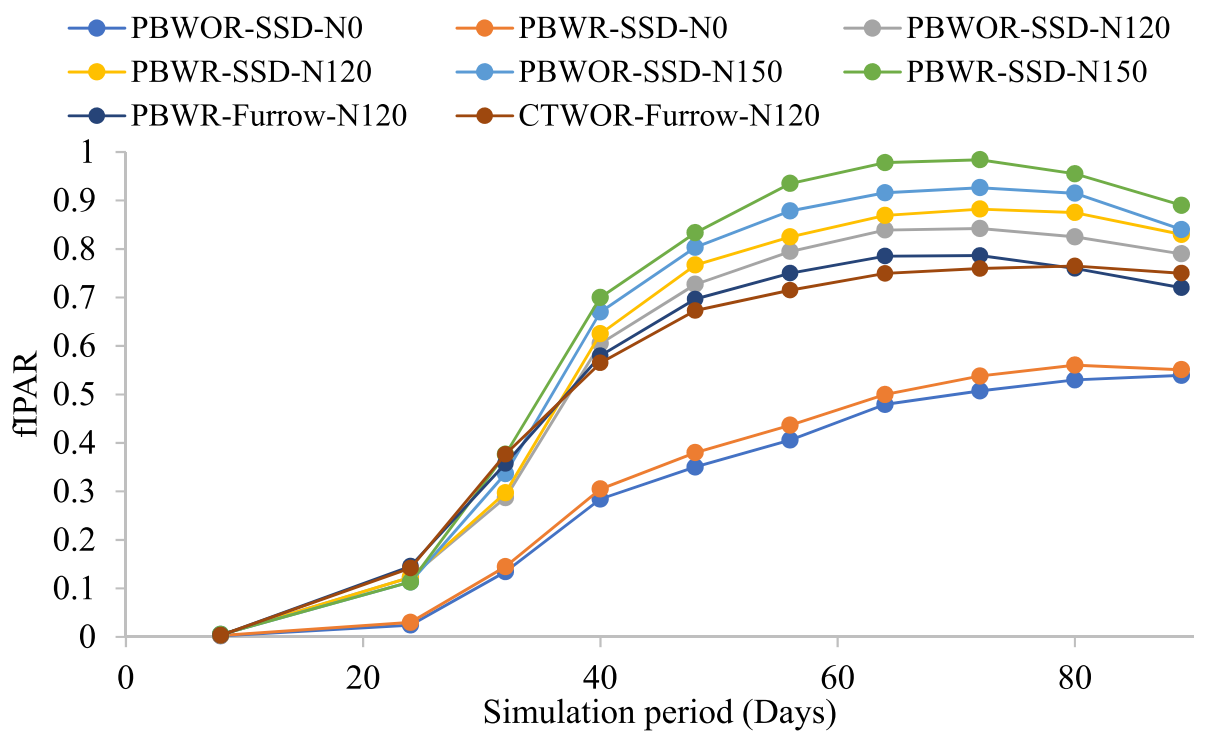

Figure 1. Effect of different tillage, residue, $N$ and irrigation management treatments on fIPAR of maize. fIPAR: Fractional Intercepted Photosynthetically Active Radiation.

that HYDRUS-2D model can be used for simulation of soil moisture dynamics effectively for all the set of treatments covering $\mathrm{CA}+$, to $\mathrm{CA}$ and conventional practices.

Soil water balance components. Evaporation. The daily evaporation and root water uptake of all treatments are presented in Figs. 3 and 4, respectively. During the initial 20 days of simulation (28 DAS) daily root water uptake from different treatments were negligible (Fig. 4), while daily evaporation ranged between 0.8 to $2.7 \mathrm{~mm} \mathrm{day}{ }^{-1}$. In treatments without $\mathrm{N}$ fertilization (N0), evaporation losses were comparatively higher (1.4$4.0 \mathrm{~mm} \mathrm{day}^{-1}$ ) than $\mathrm{N}$-fertilized treatments. After the initial 20 days of simulation, the contrasting effect of CA+, $\mathrm{CA}$ and $\mathrm{CT}$ along with $\mathrm{N}$ doses and irrigation methods on daily evaporation rate became prominent (Fig. 3). The highest cumulative evaporation $(195.6 \mathrm{~mm})$ was observed for PBWOR-SSD-N0, while the minimum cumulative evaporation $(85.3 \mathrm{~mm}$ ) was recorded for PBWR-SSD-N150 (Table 1). The cumulative evaporation losses from the CA+ treatments with N, i.e., PBWR-SSD-N150 and PBWR-SSD-N120 were $24 \%$ and $10 \%$ lower than CA treatment PBWR-Furrow-N120. Similarly, PBWR-SSD-N150 and PBWR-SSD-N120 recorded $~ 36 \%$ and $24 \%$ less evaporation compared to conventional-CTWOR-Furrow-N120.

Root water uptake. The root water uptake during the simulation period followed an opposite trend to that of daily evaporation. The peak root water uptake was commenced during 44th to 55th day of simulation which ranged between 5.8 to $6.4 \mathrm{~mm} \mathrm{day}^{-1}$ (PBWR-SSD-N150), 5.2 to $6.2 \mathrm{~mm} \mathrm{day}^{-1}$ (PBWOR-SSD-N150), 4.4 to

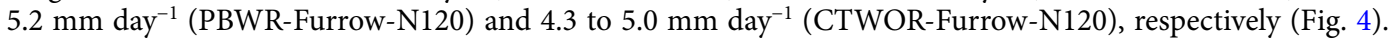
$\mathrm{N}$ application at $150 \mathrm{~kg} \mathrm{ha}^{-1}$ and $120 \mathrm{~kg} \mathrm{ha}^{-1}$ increased the daily root water uptake over N0 (without N application) by $\sim 3.3$ and $2.6-\mathrm{mm} \mathrm{day}^{-1}$, respectively during peak period (Fig. 4) and cumulative root water uptake (CRWU) by $179 \%$ and $133 \%$, respectively. Switching from the CA to CA+ (CA+SSDI) increased the CRWU by $14 \%$ (PBWR-SSD-N120 vs. PBWR-Furrow-N120). However, CA yielded $21 \%$ higher CRWU as compared to conventional practice (CTWOR-SSD-N120). Interestingly, root water uptake of CA+ at N rate of $150 \mathrm{~kg} \mathrm{~N} \mathrm{ha}^{-1}$ (PBWR-SSD-N150) was 48\% over CT (CTWOR-SSD-N120). The additional $30 \mathrm{~kg} \mathrm{~N} \mathrm{ha}^{-1}$ in CA+ increased CRWU by $23 \%$ (PBWR-SSD-N150 vs. PBWR-SSD-N120).

Deep drainage. Adoption of SSDI leads to a reduction in deep drainage (DD) loss. Among the treatments, PBWR-SSD-N150 showed the lowest deep drainage (DD) loss, while the highest value was recorded for PBWRFurrow-N120 (Table 2). The CA+ treatment PBWR-SSD-N120 and PBWR-SSD-N150 recorded 80 and $100 \mathrm{~mm}$ less DD as compared to the average of CA and CT, respectively (Table 1). Moreover, nearly $9 \%$ less DD loss was observed with an additional $30 \mathrm{~kg} \mathrm{~N}$ application $\mathrm{ha}^{-1}$ in PBWR-SSD-N150 over PBWR-SSD-N120. The largest fraction of applied water was lost as DD in CA-based plots, i.e., PBWR-Furrow-N120 plots (56\%) and CTWORFurrow-N120 (54\%) (Table 2). Total water lost by DD from CA+ plots was $21 \%$ less than FI plots (CTWORFurrow-N120, PBWR-Furrow-N120).

Variation in soil water balance components and irrigation water saving. In the current study, we have divided the entire simulation period into three phases (Phase-I, Phase-II, Phase-III) to correlate/justify the variation of water input-output relation and crop growth over time (Fig. 5). For in-depth analysis we have selected two $\mathrm{CA}+$, one CA alone and one conventional treatment viz., CA+ (PBWR-SSD-N120, PBWR-SSDN150), CA (PBWR-Furrow-N120) and Conventional (CTWOR-Furrow-N120). Phase-I ranges from 1 to 13 DOS (8-20 DAS) corresponding to low rainfall and low canopy coverage, phase-II from 14 to 52 DOS (21-59 
PBWOR-SSD-N0

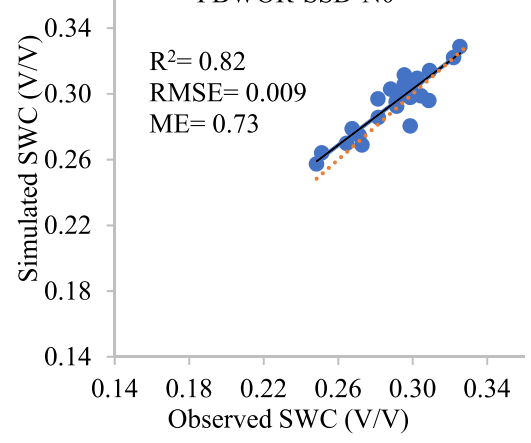

PBWOR-SSD-N120

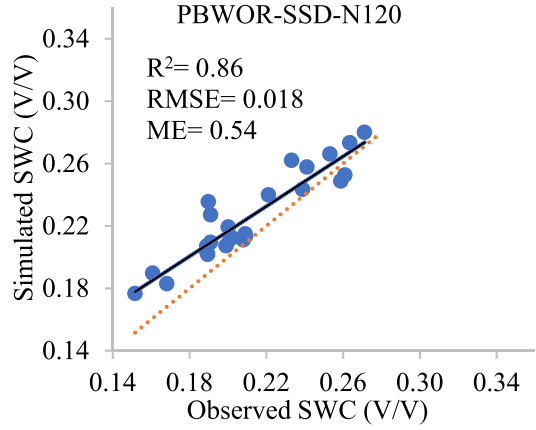

PBWOR-SSD-N150

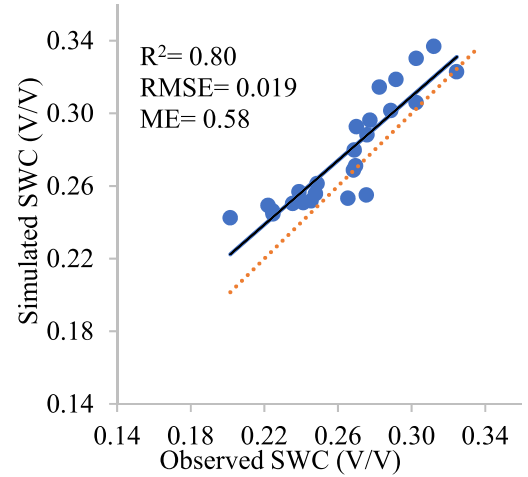

CTWOR-Furrow-N120

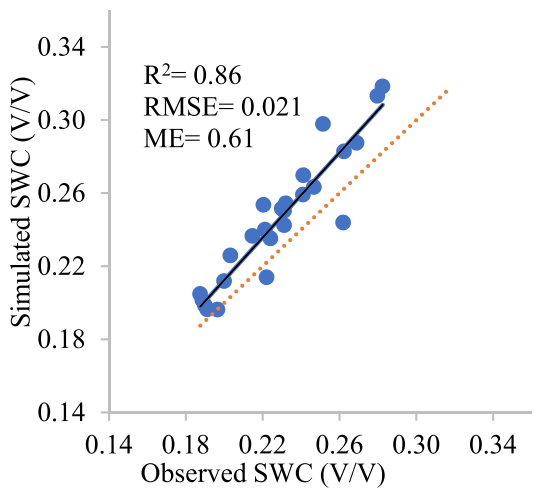

PBWR-SSD-N0

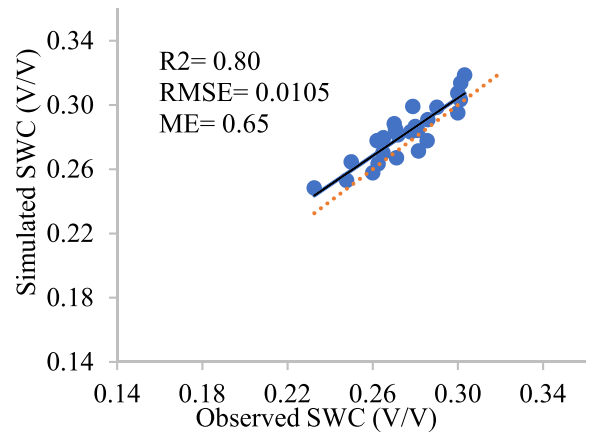

PBWR-SSD-N120

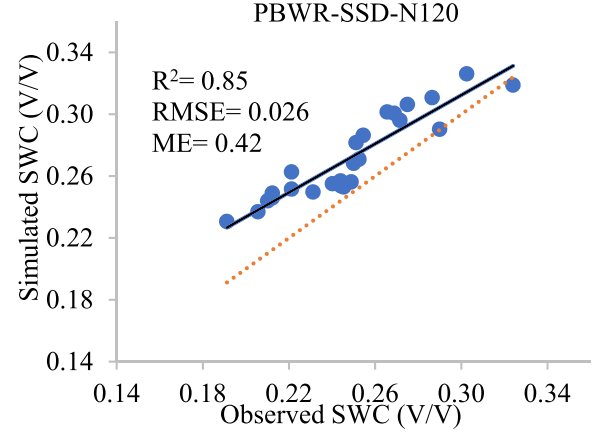

PBWR-SSD-N150

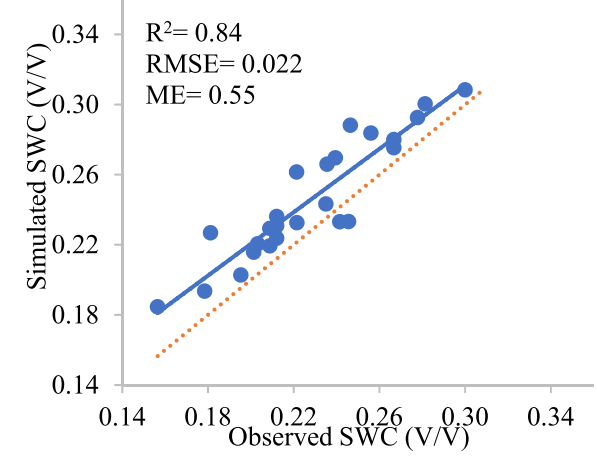

PBWR-Furrow-N120

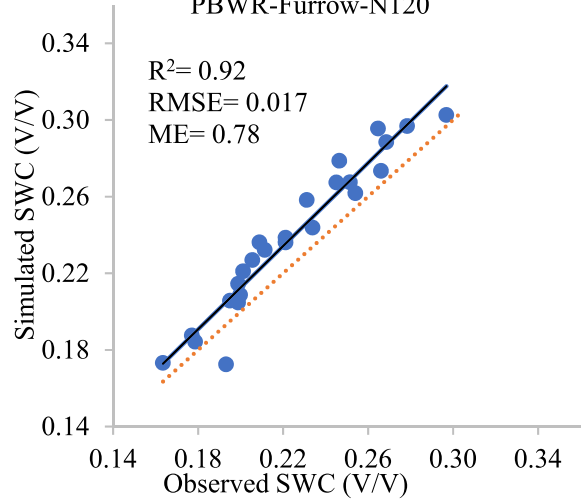

Figure 2. Observed and simulated soil water contents (SWCs) under different tillage, residue, $\mathrm{N}$ and irrigation management treatments. RMSE: Root Mean Square Error; ME: Model efficiency. For treatment detail please see Table 4 . The continuous line is the relation between observed vs predicted and dotted line is 1:1 line. 


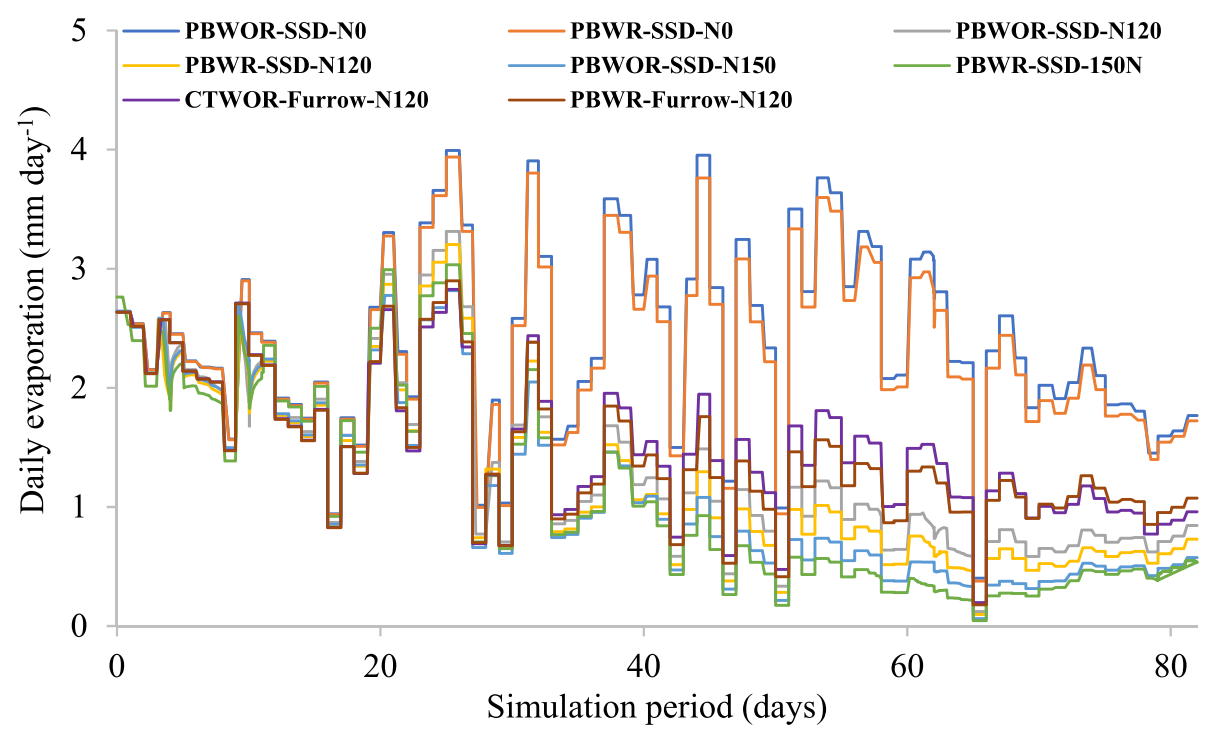

Figure 3. Daily evaporation $\left(\mathrm{mm} \mathrm{day}^{-1}\right)$ pattern during the simulation period in maize under different tillage, residue, $\mathrm{N}$ and irrigation treatments. For treatment detail please see Table 4.

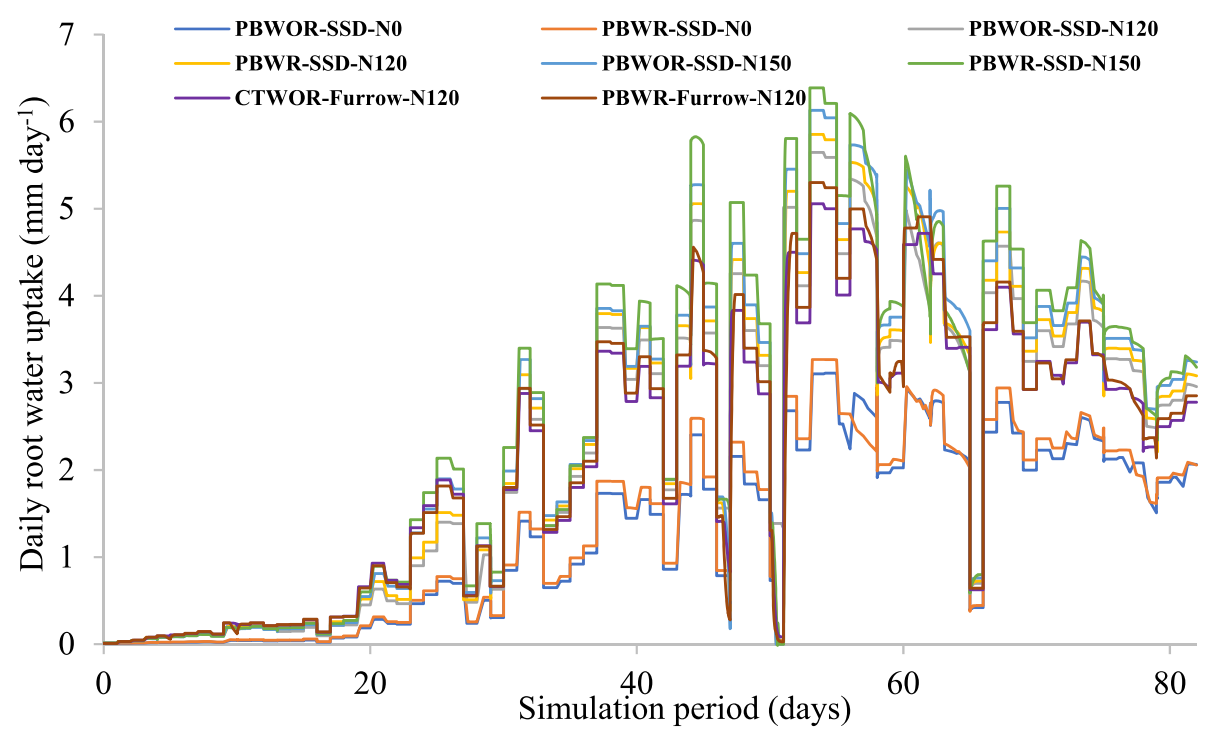

Figure 4. Daily root water uptake $\left(\mathrm{mm} \mathrm{day}^{-1}\right)$ pattern during the simulation period in maize under contrasting tillage, residue, $\mathrm{N}$ and irrigation treatments. For treatment detail please see Table 4.

DAS) with very high rainfall and moderate growth rate and Phase-III from 53 to 82 DOS (60-80 DAS) corresponding to moderate rainfall and peak crop growth rate. The rainfall received during Phase-I, phase-II and phase-III were 8,321 and $73 \mathrm{~mm}$, respectively.

In phase-I, the CRWU was very low in all treatments and the evaporation and DD components dominate as the sink of applied water. During this phase, FI-based plots (PB-Furrow-N120 and CT-Furrow-N120) received more than $50 \mathrm{~mm}$ of irrigation but that did not bring about any significant change to CRWU. The CRWU in the four treatments varied between 1.2 to $1.4 \mathrm{~mm}$. The CA+ plots recorded an average 93\% less DD signifying a huge potential of irrigation water saving during the initial crop phase when demand is very less. Irrespective of irrigation methods, in phase-I almost equal cumulative evaporation (CE) was recorded from all the treatments. In phase-II and III, average CRWU from SSDI-based plots were $96.7 \mathrm{~mm}$ and $95.5 \mathrm{~mm}$, respectively, which amounts $70 \%$ and $20 \%$ over that of FI-based plots (CA alone and CT treatment). During phase-II and III, the CA+ (PBWR-SSD-N120) had $12 \%$ and $40 \%$ less cumulative evaporation, compared to CA plots, respectively. Increasing the $\mathrm{N}$ amount from 120 to $150 \mathrm{~kg} \mathrm{ha}^{-1}$ in the $\mathrm{CA}+$ plots curtailed additional $3.0 \%$ and $10 \%$ cumulative evaporation loss during phase-II and Phase-III, while increasing the CRWU by $25 \%$ and $14.2 \%$, respectively. Maximum CRWU was recorded during Phase-III (60-80 DAS) which was 89.2, 101.9, 81.9 and $78.9 \mathrm{~mm}$ for PBWR-SSD-N120, PBWR-SSD-N150, PBWR-Furrow-N120 and CTWOR-Furrow-N120 plots, respectively. 


\begin{tabular}{|l|l|l|l|l|l|l|l|r|}
\hline Treatments $^{\mathbf{a}}$ & CRWU $(\mathbf{m m})$ & $\mathbf{C E}(\mathbf{m m})$ & $\mathbf{C D D}(\mathbf{m m})$ & SWC Initial $(\mathbf{m m})$ & SWC Final $(\mathbf{m m})$ & $\begin{array}{l}\text { CVF } \\
(\mathbf{m m})\end{array}$ & CI $(\mathbf{m m})$ & SWB \\
\hline PBWOR-SSD-N0 & 66.0 & 195.6 & 245.0 & 117.0 & 106.5 & 100 & 391.2 & -0.50 \\
\hline PBWR-SSD-N0 & 73.9 & 189.2 & 228.2 & 111.2 & 110.4 & 100 & 391.2 & 0.06 \\
\hline PBWOR-SSD-N120 & 156.2 & 110.8 & 232.3 & 81.6 & 76.7 & 100 & 391.2 & -0.31 \\
\hline PBWR-SSD-N120 & 170.3 & 101.5 & 221.5 & 98.2 & 90.1 & 100 & 391.2 & 0.60 \\
\hline PBWOR-SSD-N150 & 181.4 & 93.1 & 224.8 & 97.1 & 94.6 & 100 & 391.2 & -0.55 \\
\hline PBWR-SSD-N150 & 208.6 & 85.3 & 201.1 & 78.2 & 82.9 & 100 & 391.2 & -0.86 \\
\hline $\begin{array}{l}\text { CTWOR-Furrow- } \\
\text { N120 }\end{array}$ & 141.1 & 133.6 & 298.0 & 105.6 & 94.1 & 0 & 551.2 & -0.99 \\
\hline $\begin{array}{l}\text { PBWR-Furrow- } \\
\text { N120 }\end{array}$ & 149.6 & 112.5 & 302.5 & 104.3 & 95.5 & 0 & 551.2 & -0.46 \\
\hline
\end{tabular}

Table 1. Soil water balance (SWB) components computed by using HYDRUS-2D for simulation period (8-89 DAS) of maize. CRWU: cumulative root water uptake; CE: cumulative evaporation; CDD: cumulative deep drainage; SWC Initial: Initial (on the first day of simulation) cumulative soil-water content (mm) in soil profile up to $45 \mathrm{~cm}$ depth; SWC Final: Total soil water content in $45 \mathrm{~cm}$ depth of soil on the last day (82th) of simulation; CVF: cumulative variable flux; CI: cumulative infiltration (rainfall + irrigation) for treatments with furrow irrigation and only rainfall for treatments with subsurface drip irrigation; SWB: soil water balance. ${ }^{\mathrm{a}}$ For treatment detail please see Table 4.

\begin{tabular}{|l|l|l|}
\hline \multirow{2}{*}{ Treatments } & \multicolumn{2}{l|}{ Crop duration (113 days) } \\
\cline { 2 - 3 } & Irrigation water applied (mm) & Irrigation water saving (\%) \\
\hline Plots with furrow irrigation & 240 & - \\
\hline Plots with subsurface drip irrigation & 140 & 41.6 \\
\hline Treatments & Cumulative inflow (mm) & Total water loss (\%) \\
\hline PBWOR-SSD-N0 & 491.2 & 49.88 \\
\hline PBWR-SSD-N0 & 491.2 & 46.45 \\
\hline PBWOR-SSD-N120 & 491.2 & 47.29 \\
\hline PBWR-SSD-N120 & 491.2 & 45.09 \\
\hline PBWOR-SSD-N150 & 491.2 & 45.76 \\
\hline PBWR-SSD-150N & 491.2 & 40.94 \\
\hline CTWOR-Furrow-N120 & 551.2 & 54.06 \\
\hline PBWR-Furrow-N120 & 551.2 & 55.88 \\
\hline
\end{tabular}

Table 2. Cumulative inflow and water-saving under different tillage, residue, irrigation and nitrogen management treatments. ${ }^{\text {a }}$ For treatment detail please see Table 4.

Adoption of SSDI led to $\sim 62 \%$ and $~ 38 \%$ irrigation water saving during phase-I and phase-III, respectively, over conventional FI. Overall, in SSDI plots $41.6 \%$ irrigation water saving was recorded (on application basis) over conventional FI in maize crop (Table 2).

Soil water content. Depth-wise mean moisture content and variation in soil moisture during the simulation period is depicted in Fig. 6. In SSDI plots, mean moisture content was lowest at the surface $(0-5 \mathrm{~cm})$ soil depth, then showed an increasing trend up to $15-30 \mathrm{~cm}$ (the zone where the laterals were laid in) and again decreased at 30-45 cm depth, indicating a reduction of both evaporation and DD loss. Across depth, mean soil moisture content in the CA+-based PBWR-SSD-N150 plots ranged from $21 \%$ to 25\% (Fig. 6a), whereas in the case of CT it ranged from $\sim 20 \%$ to $29 \%$ (Fig. 6b). In FI-based treatment, the highest mean moisture content (30.9\% and $29.7 \%$ for CA and CT respectively) was observed at 5-10 $\mathrm{cm}$ soil depth followed by surface $0-5 \mathrm{~cm}$ soil depth. In SSDI plots, the highest variations (CV) in moisture content (36-41\%) was at surface soil and gradually decreased along with the depth, whereas an opposite trend was observed in furrow-irrigated plots (Fig. 6a,b). Overall, variations in moisture content throughout the soil profile were least in CA treatment (PBWR-Furrow-N120) (19\% to 21\%) followed by CT (CTWOR-Furrow-N120) (22 to 23\%). The minimum soil moisture variability in CA and CT plots was observed at $0-5 \mathrm{~cm}$ soil depth followed by $5-10 \mathrm{~cm}$ depth. However, the soil moisture variability of CA+ plots was found to be dropped by $11.2,12.3$ and $27.3 \%$ for $10-15,15-30$ and 30-45 cm soil depths, respectively, as compared to average values of corresponding depths of FI plots (Fig. 6a,b).

Radiation use efficiency, crop biomass yield and water productivity. Radiation use efficiency (RUE) is a function of $\mathrm{N}$ application rate. A similar RUE was recorded for all plots received sufficient rate of $\mathrm{N}$ (120 and $150 \mathrm{~kg} \mathrm{~N} \mathrm{ha}^{-1}$ ), irrespective of tillage, irrigation and residue management options (Table 3). Moreover, treatments without $\mathrm{N}$ application showed significantly lower RUE as compared to $\mathrm{N}$-fertilized treatments 
Phase I

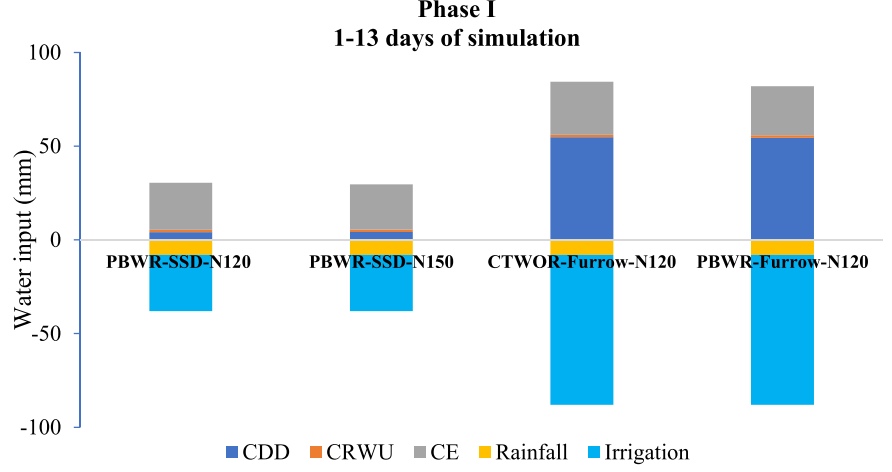

Phase II

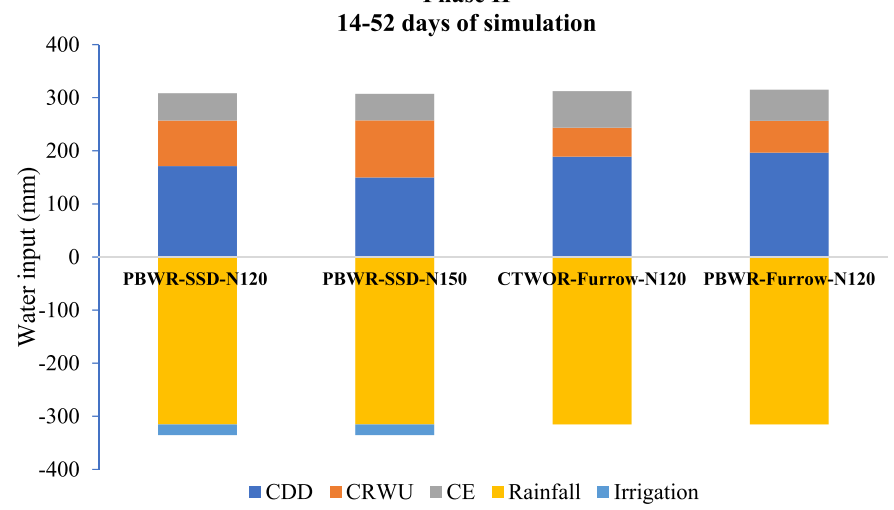

Phase III

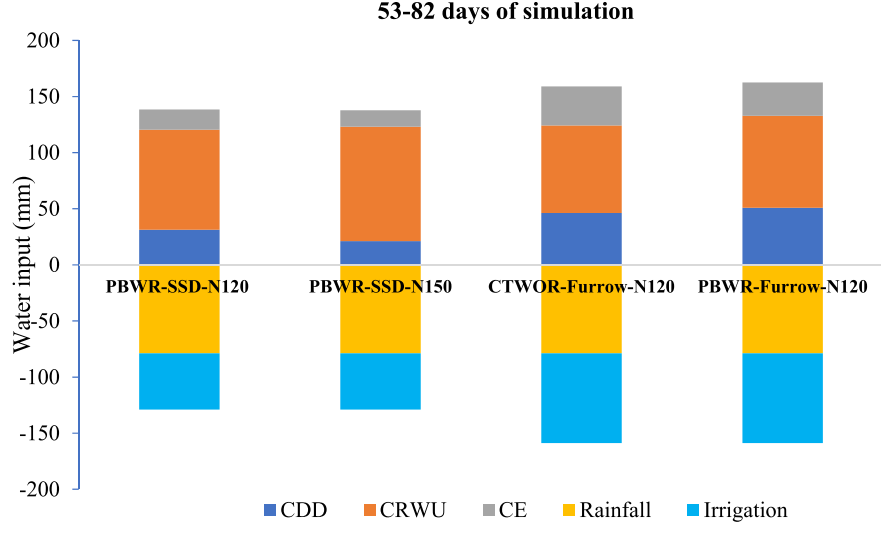

Figure 5. Partitioning of water input and output components in maize under contrasting tillage, residue, $\mathrm{N}$ and irrigation management treatments. Where, CDD: cumulative deep drainage; CRWU: cumulative root water uptake; CE: cumulative evaporation. Units of all parametersare in $\mathrm{mm}$. ${ }^{\star}$ For treatment detail please see Table 4.

(Table 3). During the simulation period, the highest biomass accumulation was recorded for PBWR-SSD-N150 plots $\left(19,260 \mathrm{~kg} \mathrm{ha}^{-1}\right)$ (Table 3). All N-fertilized CA+ treatments had a significantly higher dry matter accumulation as compared to FI-based plots (CTWOR-Furrow-N120 and PBWR-Furrow-N120). At a similar N-rate, the biomass accumulated in the CA+-based PBWR-SSD-N120 was $20 \%$ and $16 \%$ higher than that of CT and CA plots, respectively.

In this study, the water productivity (WP) was estimated based on two different aspects and is presented in Table 3. Based on total water use (rainfall and irrigation), the highest WP $\left(39.2 \mathrm{~kg} \mathrm{ha}^{-1} \mathrm{~mm}^{-1}\right)$ was observed for PBWR-SSD-N150 treatment which was at par with PBWOR-SSD-N150 and significantly higher than rest of the treatments. On the basis of evapo-transpiration, the WP of different treatments followed a similar pattern as of water use (rainfall and irrigation) basis. Despite the application of an equal amount of $\mathrm{N}$ doses, the WP (based on evapo-transpiration ET; CRWU + CE) of CA+ (PBWR-SSD-N120) was 11.4 and $21.7 \%$ higher than CA and CT treatment. 


\begin{tabular}{|c|c|c|c|c|}
\hline \multirow[b]{2}{*}{ Treatments $^{\mathrm{a}}$} & \multirow[b]{2}{*}{$\begin{array}{l}\text { Dry matter accumulation } \\
\left(\mathrm{kg} \mathrm{ha}^{-1}\right)\end{array}$} & \multirow[b]{2}{*}{ RUE (DM basis) $\left(\mathrm{g} \mathrm{MJ}^{-1}\right)$} & \multicolumn{2}{|c|}{ Water productivity $\left(\mathrm{kg} \mathrm{ha}^{-1} \mathrm{~mm}^{-1}\right)$} \\
\hline & & & Crop WP : $\frac{D M}{(\mathrm{CRWU}+\mathrm{CE})}$ & Field WP $: \frac{D M}{\text { Waterinflow }}$ \\
\hline PBWOR-SSD-N0 & $3770 \mathrm{~d}$ & $2.04 \mathrm{~b}$ & $14.41 \mathrm{~d}$ & $7.68 \mathrm{~d}$ \\
\hline PBWR-SSD-N0 & $4145 \mathrm{~d}$ & $2.11 \mathrm{~b}$ & $15.75 \mathrm{~d}$ & $8.44 \mathrm{~d}$ \\
\hline PBWOR-SSD-N120 & $16686 \mathrm{~b}$ & $4.75 \mathrm{a}$ & $62.50 \mathrm{ab}$ & $33.98 \mathrm{~b}$ \\
\hline PBWR-SSD-N120 & $16906 \mathrm{~b}$ & $4.78 \mathrm{a}$ & $62.20 \mathrm{ab}$ & $34.42 \mathrm{~b}$ \\
\hline PBWOR-SSD-N150 & 17497ab & $4.89 \mathrm{a}$ & $63.74 \mathrm{a}$ & $35.63 \mathrm{ab}$ \\
\hline PBWR-SSD-N150 & $19260 \mathrm{a}$ & $4.93 a$ & $65.53 a$ & $39.22 \mathrm{a}$ \\
\hline CTWOR-Furrow-N120 & $14031 \mathrm{c}$ & $4.50 \mathrm{a}$ & $51.08 \mathrm{c}$ & $25.41 \mathrm{c}$ \\
\hline PBWR-Furrow-N120 & $14639 \mathrm{c}$ & $4.57 \mathrm{a}$ & $55.85 \mathrm{bc}$ & $26.51 \mathrm{c}$ \\
\hline
\end{tabular}

Table 3. Dry matter accumulation, radiation use efficiency (RUE) and water productivity of maize under different tillage, crop residue, nitrogen and irrigation management treatments during the simulation period (8-89 DAS). Means followed by different lowercase letter within each column are significantly different (at $\mathrm{P}<0.05)$ according to least significant difference test. ${ }^{a}$ For treatment detail please see Table 4.

\section{Discussion}

The challenge of water scarcity is increasing and becoming complex overtime, therefore, it is highly imperative to think beyond CA and to couple it with best-fit technologies, i.e., precision $\mathrm{N}$ and water application through SSDI $(\mathrm{CA}+)$ to minimize water loss, while increasing productivity, profitability and maintaining soil health.

Soil water balance. The lower evaporation from CA-based plots was because of insulation properties of crop residues against solar radiation ${ }^{35}$, therefore allowing less energy flux into the soil, and decrease soil temperature ${ }^{36}$ and evaporation from the soil surface ${ }^{37,38}$. Crop residue also impeded water vapour diffusion and reduces wind speed at the soil-atmosphere interface ${ }^{39}$. Moreover, better plant growth was observed in CA+ treatments due to efficient water and $\mathrm{N}$ management, with simultaneous increase in radiation interception and decrease in evaporation. More importantly, in CA+ (CA and SSDI) avoiding wetting the soil surface $(0-5 \mathrm{~cm})$ through direct water application into the root zone at a depth of $15-20 \mathrm{~cm}$ led to a significant reduction in evaporation losses ( $24-36 \%$ decrease in evaporation over CT). Similar to our results, Evett et al. ${ }^{40}$ reported lower soil evaporation under SSDI compared to FI. In the current study, despite receiving $100 \mathrm{~mm}$ of higher irrigation water over SSDI (during the entire season), the FI plots showed higher variability in soil moisture content in the root zone, which could be due to the higher DD and evaporation as compared to SSDI plots.

Adoption of CA+ not only reduced evaporation but also decreased DD losses. The highest DD loss from FI plots (Table 1), could be due to the application of a higher amount of irrigation water as compared to SSDI plots. Moreover, in FI system, the high-water infiltration into the soil from lateral (seepage) and vertical direction from a larger surface area (compared to SSDI, where the materials are below the soil surface), makes the soil saturated in a short period, thereby facilitating higher $\mathrm{DD}^{9}$. Patra et al. ${ }^{41}$ reported the formation of more water-conducting macropores, as well as biogenic pores in residue retained long-term PB plots, which make the soil more amiable for DD loss. In contrast, under CT condition soil structure and water-conducting pores were destroyed due to repetitive and intensive tillage operations ${ }^{42}$, which resulted in slightly lower DD in CT compared to CA.

A positive integration between $\mathrm{N}$-fertigation (up to $150 \mathrm{~kg} \mathrm{~N} \mathrm{ha}^{-1}$ ) through SSDI and residue retention was observed for root water uptake (Table 1). Between CA and CT plots, the higher root water uptake under CA (PBWR-Furrow-N120) treatment might be due to the fact of surface residue retention, which added additional nutrients to the soil, improved soil structure and root aeration. Moreover, the partitioning of water towards root water uptake under SSDI plots was higher due to lesser DD and evaporation losses. Phase-wise speaking, the higher DD losses in furrow irrigated plots during phase-I (1-13 DOS) was mainly due to the application of $50 \mathrm{~mm}$ more irrigation water than SSDI plots (Fig. 5). During phase-I, the root water uptake was very low, because crop canopy coverage and root growth were almost negligible, thus most of the applied water was lost by evaporation and DD. Therefore, precise irrigation water application through SSDI during phase I saved crop from water stress and aided to maintain turgidity, normal cell functioning without substantial losses. As crop proceeded towards phase II and phase-III, the transpiration dominated over evaporation and thus curtailed overall water losses. So, phase-II and III of CA+ can be summarized as diversion of water more towards CRWU by reducing evaporation and DD through precise water management using SSDI system. The highest root water uptake was recorded at Phase-III (between 60-80 DAS) (Fig. 5). Similar to Hydrus-2D model simulated finding, the highest consumptive use of maize at 55-82 DAS was also reported by Zegada-Lizarazu et al. ${ }^{43}$.

Soil moisture variability. The decreased soil moisture variability in the root zone under CA+ was due to the controlled and frequent water application. However, in CT plots, the higher variability in soil moisture along the soil profile could be due to reduced water-stable aggregates, which gets further disrupted during drying and wetting tillage practices ${ }^{44}$. Thus, irrespective of the amount of water applied through furrow and SSDI methods, $\mathrm{CA}+$ plots may act as a buffer for change in soil moisture content within the root zone.

Across the treatments, the mean moisture content at almost all depths was higher for SSDI irrigated plots when crop residue was retained (PBWR-SSD-N120 and PBWR-SSD-N150). The line source drip laterals were laid 

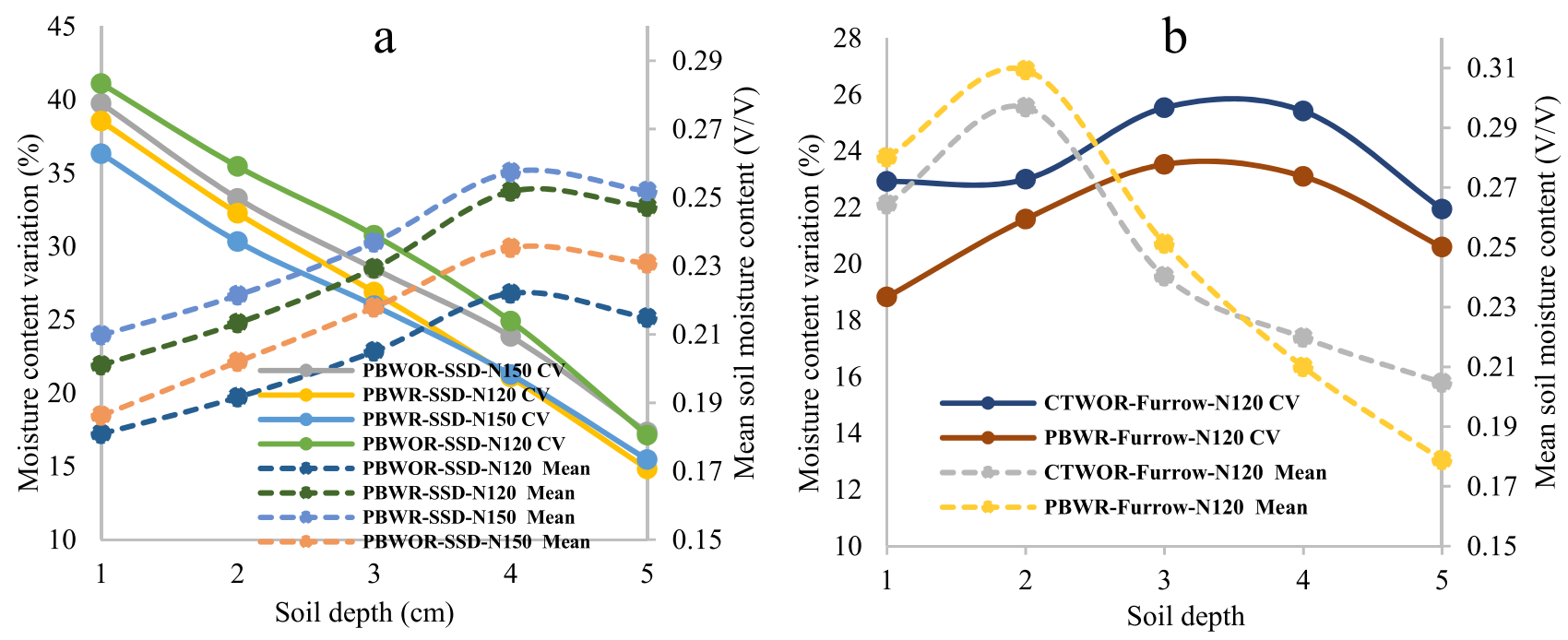

Figure 6. Variability in soil moisture content (primary axis) and mean moisture content (V/V) (secondary axis) of treatments with SSD and furrow irrigation during simulation period (8-89 DAS). Soil depth 1,2,3,4 and 5 corresponds to $0-5 \mathrm{~cm}, 5-10 \mathrm{~cm}, 10-15 \mathrm{~cm}, 15-30 \mathrm{~cm}$ and $30-45 \mathrm{~cm}$ soil depths, respectively. For treatment details please see Table 4 .

at $20 \mathrm{~cm}$ soil depth, which resulted in higher mean moisture content with least variability in $15-30 \mathrm{~cm}$ soil depth of SSDI plots (Fig. 6a,b). Reduced moisture content in surface soil justifies reduced rate of surface evaporation from SSDI plots. Also, crops in SSDI plots withdrew water from subsurface soil depth and accumulated higher biomass compared to FI treatments. In contrast, in FI treatments, the highest mean moisture and lowest CV were observed at the second soil layer $(5-10 \mathrm{~cm}$, just adjacent to the surface $0-5 \mathrm{~cm}$ ) (Fig. 6b). In the experiment less variability in moisture content was observed in CA plots compared to CT plots. Similar results also reported by Parihar et al. ${ }^{9}$ with a justification that the lower mean weight diameter of soil aggregates in CT plots resulted in more unregulated sorption and desorption pattern of soil.

Plant growth, RUE, LAI and WP. CA+ practices avoid extreme moist and dry conditions and help in maintaining optimum soil moisture content in the effective root zone. This facilitates higher root water uptake and crop growth, better canopy structure, higher leaf area index (LAI) in CA+ and ultimately resulted in higher light interception ${ }^{45}$. Moreover, $\mathrm{N}$-fertigation through SSDI saves a considerable amount of $\mathrm{N}$ from leaching losses and a larger fraction of $\mathrm{NO}_{3}-\mathrm{N}$ remains readily available in the root zone for crop uptake ${ }^{46}$ Further, in the present study, irrigation was scheduled based on soil matric potential (below. $-50 \mathrm{kPa}$ ) in all CA+ plots, whereas it was based on critical crop growth stages in the case of CA and CT plots. Consequently, under FI plots, the high DD losses might have led to less $\mathrm{N}$-availability due to potential $\mathrm{NO}_{3}$ leaching and slight water deficit in between two subsequent irrigations, therefore may cause reduction in plant growth. Higher LAI values of maize in notillage with residue retained condition was also reported by Bergamaschi et al. ${ }^{4}$.

The high dry-matter accumulation in CA+ plots, in particular, PBWR-SSD-N150 treatment could be due to precise and sufficient $\mathrm{N}$ and water application, in addition to residue retention. Interestingly, at the same $\mathrm{N}$ amount $\left(120 \mathrm{~kg} \mathrm{ha}^{-1}\right)$ the higher $\left(2.26 \mathrm{t} \mathrm{ha}^{-1}\right)$ biomass accumulation of PBWR-SSD-N120 over PBWR-Furrow$\mathrm{N} 120$ was solely due to efficient $\mathrm{N}$ and water management through SSDI. The $0.6 \mathrm{t} \mathrm{ha}^{-1}$ higher biomass accumulation in PBWR-Furrow-N120 over CTWOR-Furrow-N120, could be due to residue retention- and least soil disturbance across years (since 2014). The water productivity (WP) of different treatments also followed a similar trend as biomass accumulation (Table 3). The high WP of N-fertilized SSDI is mainly due to reduced water losses, while producing significantly higher dry biomass compared to CA and CT treatments. Despite the application of $60 \mathrm{~mm}$ more water during simulation period, proportionally lesser biomass was produced per unit of applied water under FI treatments. Among FI treatments, higher WP was observed in CA than that of CT. In agreement with the present findings, Parihar et al. ${ }^{48}$ also reported higher WP in CA-based PB systems as compared to CT. Results of the current study showed that CA+ treatments is more efficient in converting captured solar radiation into biomass thereby, recorded higher radiation use efficiency (RUE) (Table 3). While, lower RUE in FI plots was mainly due to poor canopy development which resulted in less radiation interception. Furthermore, RUE is a function of $\mathrm{LAI}^{49}$ and as discussed earlier, higher LAI was recorded under SSDI. A water-saving of $41.6 \%$ was achieved under CA+ over CA and CT. In a study Lamm and Trooien ${ }^{50}$ were also reported $35-55 \%$ saving of irrigation water under SSDI over FI. The reduction in irrigation requirement in SSDI plots was mainly because of reduced soil evaporation, decreased deep percolation and elimination of runoff losses ${ }^{51}$. Overall, in the present study, SSDI coupled with CA-practices at sufficient $\mathrm{N}$ application resulted in the highest moisture content, lowest variability the most effective root-zone layer (15-30 cm soil depth). Lower evaporations and DD losses, led to a higher cumulative root-water uptake, higher biomass accumulation, and ultimately higher WP. Despite the encouraging/promising results, further long-term studies should be conducted. 


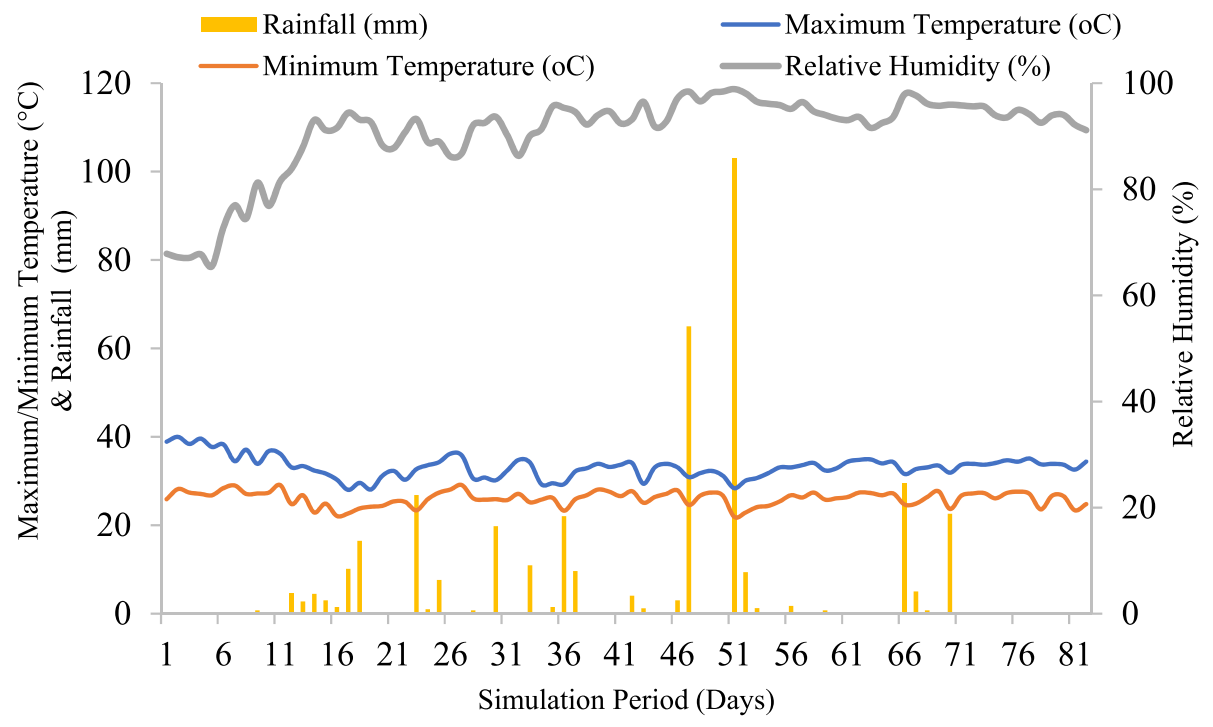

Figure 7. Daily weather conditions during simulation period (Day 1 corresponds to 28 th June, 2019 and the day 82 corresponds to 17 th Sep, 2019).

\section{Conclusions}

Our research investigation has provided the first science-based evidence (using Hydrus-2D) on basic and in-depth scientific insights on soil water balance components for irrigation water saving, improving water productivity, radiation use efficiency and crop biomass yield under concurrent use of subsurface drip irrigation (SSDI) and conservation agriculture (CA) in maize grown in rotation with wheat. The results showed that bundling of complementing agronomic innovations like conservation agriculture (CA) coupled with subsurface drip irrigation (SSDI) and fertigation can be a sustainable option to address the emerging issues of water scarcity, declining groundwater table and shrinking and degraded natural resources. There is a huge potential for water savings in $\mathrm{CA}+$ by minimizing the deep drainage and evaporation losses and potentially diverting the soil moisture use for consumptive uses. The healthy soil as a result of CA and CA+ favours more crop growth in terms of leaf area production, light interception and biomass production. So CA+ $(\mathrm{CA}+\mathrm{SSDI})$ is a better option/practice for irrigation water saving, soil moisture conservation, precision irrigation and nutrient management. Retaining crop residues on the soil surface as mulch is an alternative to in-situ crop residue burning. Besides, reduction in denitrification and volatilization losses through fertigation using SSDI system in CA will also help in reducing global warming potential in the long-run. Considering the future consequences of rapidly depleting groundwater resources, the provincial Governments in Punjab and Haryana as well as the Government of India have initiated a new policy program ("more crop per drop", Water is Life, Direct Benefit Transfer of Electricity, etc.) for saving of water in agriculture. But there is a need for 'Science driven Policy' for effective execution of these investment schemes of the Government. Therefore, the results of our study complementing agronomic innovations i.e., $\mathrm{CA}$ and SSDI $(\mathrm{CA}+)$ for cereal crops would be of immense interest to farmers, policy planners and civil society for addressing the current and future challenges of farming. In the future the $\mathrm{N}$ dynamics and $\mathrm{N}$ loss studies in SSDI installed CA-based systems $(\mathrm{CA}+)$ using Hydrus-2D model may provide further insight into this aspect.

\section{Methods}

Experimental site. A field experiment was conducted in an ongoing research trial since kharif-2014 with the same set of treatments at fixed-site at Borlaug Institute for South Asia (BISA)-International Maize and Wheat Improvement Center (CIMMYT), Ladhowal ( $30.99^{\circ} \mathrm{N}$ latitude, $75.44^{\circ} \mathrm{E}$ longitude, $229 \mathrm{~m}$ above mean sea level), Punjab, India. The experimental site comes under Trans-Gangetic Plains Zone (Agro Climatic Zone-VI) of India with a sub-tropical and semi-arid climate. The average annual rainfall of the site is $734 \mathrm{~mm}$ with hot dry summer, wet monsoon and cold winters. The site receives about $80 \%$ of its total rainfall during the monsoon season. The total amount of rainfall received during the crop growing period of Kharif-2019 was $487.95 \mathrm{~mm}$ of which $82 \%$ was received during the simulation period (28th June to 17th September, 2019). The graphical representation of daily rainfall distribution, minimum and maximum temperature and relative humidity during simulation period have been presented in Fig. 7. The soil of the study site is of alluvial origin and well-drained, sandy loam in nature with $\mathrm{pH}$ range of $7.9-8.5$ (1:2 soil water ratio) and EC $0.58 \mathrm{dS} \mathrm{m}^{-1}$.

Experimental design and details. In this study, we assessed water budgeting in conservation agriculturebased sub-surface drip irrigation (CA+), CA and conventional practices (CT) using HYDRUS-2D for maize crop in 2019 (after five years of continued CA, CA+ and CT practices). Combinations of contrasting tillage (permanent beds- $\mathrm{PB}$, and conventional tillage-CT), residue management (residue retention-WR and residue removal-WOR), irrigation methods (subsurface drip irrigation-SSDI and conventional furrow irrigation-FI) at different rates of nitrogen were adopted and SWB, water-saving, dry matter accumulation and water productiv- 


\begin{tabular}{|l|l|l|l|}
\hline Tillage and residue management options & Irrigation methods & Nitrogen applied $\left(\mathbf{k g ~ h a}^{-\mathbf{}}\right)$ & Treatment notation used \\
\hline Permanent Bed without residue & SSDI & 0 & PBWOR-SSD-N0 \\
\hline Permanent Bed with 25\% wheat residue & SSDI & 0 & PBWR-SSD-N0 \\
\hline Permanent Bed without residue & SSDI & 120 & PBWOR-SSD-N120 \\
\hline Permanent Bed with 25\% wheat residue & SSDI & 120 & PBWR-SSD-N120 \\
\hline Permanent Bed without residue & SSDI & 150 & PBWOR-SSD-N150 \\
\hline Permanent Bed with 25\% wheat residue & SSD & 150 & PBWR-SSD-N150 \\
\hline Conventional tillage (fresh bed without residue) & FI & 120 & CTWOR-Furrow-N120 \\
\hline Permanent Bed with 25\% wheat residue & FI & 120 & PBWR-Furrow-N120 \\
\hline
\end{tabular}

Table 4. Treatment details and notation used in the study. SSDI: subsurface drip irrigation; FI: furrow irrigation.

Permanent raised bed $(\mathrm{PB})$ with subsurface drip irrigation (SSDI)

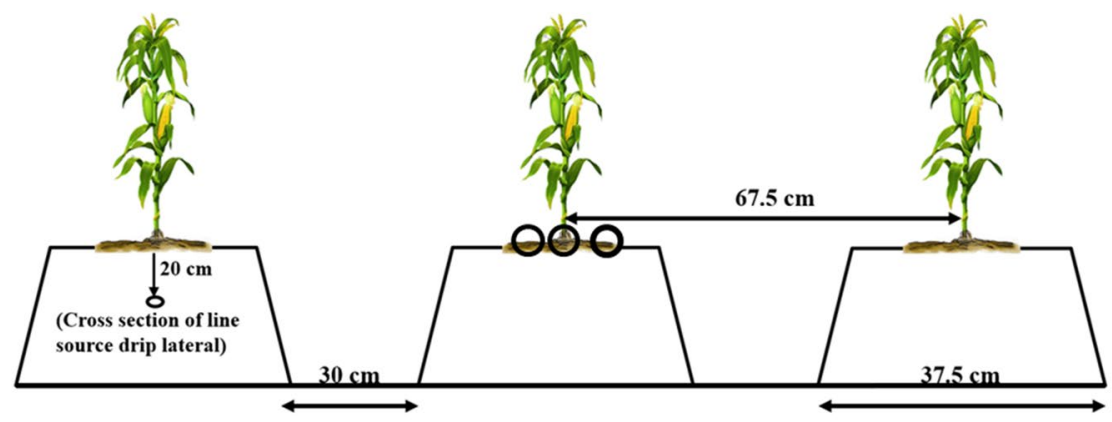

Fresh bed $(\mathrm{CT})$ or Permanent raised bed (PB) with furrow irrigation

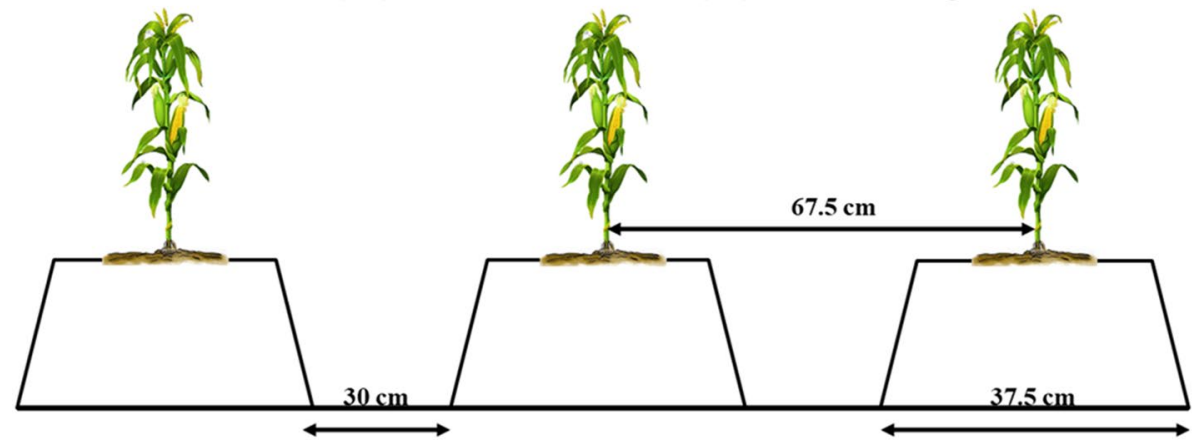

Figure 8. Land configuration and root sampling design (presented by circles) for two contrasting tillage and irrigation management options.

ity were determined. The experiment was laid out in a randomized complete block design (RCBD) (plot size: 81 $\mathrm{m}^{2}$ ) using three replications. In the current study, $6 \mathrm{CA}^{+}$treatments (CA coupled with SSDI); permanent beds using sub-surface drip (PB-SSD) with and without crop residue at different $\mathrm{N}$ rates, viz., 0,120 and $150 \mathrm{~kg} \mathrm{~N} \mathrm{ha}^{-1}$ were compared with CA (PB using furrow irrigation-FI with crop residue-120 $\mathrm{kg} \mathrm{N} \mathrm{ha}^{-1}$ ) and conventional practices (conventional tillage-CT using FI without crop residue- $120 \mathrm{~kg} \mathrm{~N} \mathrm{ha}^{-1}$ ) resulting in 8 treatments. The detail of treatments is given in Table 4 . In all the WOR plots, $100 \%$ of crop residue of both the crops was removed, while in all WR plots, $\sim 25 \%$ of preceding crop residue was retained on the soil surface since 2014 . The permanent beds (PB) were prepared in June 2014 using a bed planter and were kept undisturbed across years with little reshaping once in a year. Bed width (mid-furrow to mid-furrow), width of flat tops and furrow depth were 67.5, 37 and $15 \mathrm{~cm}$, respectively. A pictorial representation of land configuration is given in Fig. 8. In CT plots, land was prepared with one deep tillage followed by 2 ploughings with cultivators and fresh beds were prepared by bed maker. Across years, in all plots, maize variety $\mathrm{P} 3396$ was planted in June, at $67.5 \mathrm{~cm} \times 20 \mathrm{~cm}$ spacing using maize planter. A common dose of $60 \mathrm{~kg} \mathrm{P}_{2} \mathrm{O}_{5}+30 \mathrm{~kg} \mathrm{~K}_{2} \mathrm{O}$ and $25 \mathrm{~kg} \mathrm{ZNSO}_{4}$ heptahydrate ha ${ }^{-1}$ was applied to all plots as basal (directly at the time of mechanical seeding). N-fertilized treatments (PBWOR-SSD-N120, PBWR-SSDN120, PBWOR-SSD-N150, PBWR-SSD-N150, CTWOR-Furrow-N120 and PBWR-Furrow-N120) received $23.5 \mathrm{~kg} \mathrm{~N} \mathrm{ha}^{-1}$ along with the common basal dose of $\mathrm{P}_{2} \mathrm{O}_{5}$ and $\mathrm{K}_{2} \mathrm{O}$. The rest of $\mathrm{N}$ in SSDI plots (PBWORSSD-N120, PBWR-SSD-N120, PBWOR-SSD-N150 and PBWR-SSD-N150) was applied through fertigation in 
4-equal splits at 15 days interval (starting from 21 days after sowing-DAS). While in FI-plots (CTWOR-FurrowN120 and PBWR-Furrow-N120) the remaining N was top-dressed into two equal splits at the knee-high stage and pre tasselling stage of maize. In SSDI plots irrigation was scheduled based on soil matric potential using a tensiometer (IRROMETER, River-side, California), installed at $20 \mathrm{~cm}$ depth at the middle (in between two rows) of each plot. Plots were irrigated at a soil matric potential of $-50 \mathrm{kPa}$ throughout the entire crop period. During the entire crop period, for SSDI plots, $140 \mathrm{~mm}$ water was applied through 14-irrigations, with irrigation of $10 \mathrm{~mm}$ each. While in furrow irrigated plots (CTWOR-Furrow-N120 and PBWR-Furrow-N120) $240 \mathrm{~mm}$ irrigation water was applied in 6 irrigations. Out of the 6-irrigations in furrow-irrigated plots, two irrigations were given just after sowing and post-sowing (5-DAS), while the rest four irrigations were scheduled at 6 leaf, late knee-high, 50\% silking and dough stages ${ }^{52}$. In SSDI plots, the frequency of irrigation varied 2-5 days according to the growth stage, weather conditions and rainfall event. In all the SSDI plots the laterals of drip were placed at $20 \mathrm{~cm}$ soil depth at a spacing of $67.5 \mathrm{~cm}$. The inner diameter of laterals was $16 \mathrm{~mm}$ and were laid parallel to crop rows. Each lateral consisted of a line source emitter with a uniform emitter discharge of $2.0 \mathrm{~L} \mathrm{~h}^{-1}$ and were spaced at $30 \mathrm{~cm}$. More details about these automated subsurface drip-irrigated systems (installed at CIMMYTBISA Farm, Ladhowal) can be obtained from Sidhu et al. ${ }^{17}$.

Simulation period. The long term experiment had started in kharif-2014. The data for model simulation in maize crop was collected during 2019. In this experiment, we have simulated profile soil moisture distribution, soil water balance and crop root water uptake for 82 days during 8-DAS to 89-DAS of maize crop. The initial seven days, two irrigations in furrow irrigated plots and four in SSDI plots (0-8 DAS) were not considered for simulation. Such irrigations were given to ensure uniform germination in extremely hot and dry weather conditions. Therefore, the plant hardly uptake any moisture from these irrigations. Throughout the simulation period (82 days; 8th-89th DAS) a total of 11 observations from 5 consecutive soil depths $(0-5,5-10,10-15,15-30$ and $30-45 \mathrm{~cm}$ ) were taken at 8 days intervals. The model calibration and Van Genuchten-Mualem parameter optimization (Ksat, $\theta \mathrm{r}, \theta \mathrm{s}, \alpha$ and $\mathrm{n}$ ) procedure were performed using 30 data points $(5$ depths $\times 6$ times of observation) in inverse solution technique and validated against 25 data point ( 5 depths $\times 5$ times of observations). The model solves the water transport equation (Richards' equation) in each mesh unit for both calibration and validation.

Soil physical parameters measurement. For soil bulk density (BD) determination, before maize sowing (19th June 2019), undisturbed soil samples were collected from each plot in triplicate from soil depths of 0-5, $5-10,10-15$ and $15-30,30-45 \mathrm{~cm}$. The soil water content for the same soil depths was measured volumetrically (gravimetric moisture content $\times \mathrm{BD}$ ). Similarly, soil moisture content at saturation, field capacity and permanent wilting point was measured using pressure plate apparatus ${ }^{33}$. The soil texture parameters, i.e., sand, silt and clay percentages for the same depths were obtained using the Hydrometer method ${ }^{54}$.

Root sampling and scanning. The procedure for root sampling was followed as described by Aggarwal et al. ${ }^{55}$. Root samples were taken from the field at 30 and 56 DAS using a root core sampler. Three representative plants from each plot were cut from the base and roots were taken from the center $(0,0)$ and $2 \mathrm{~cm}$ left and right from the periphery at $0-15,15-30$ and $30-45 \mathrm{~cm}$ soil depths. The collected samples were taken in a tray and soaked for $24 \mathrm{~h}$ to separate roots from the adhered soil. A pinch of sodium hexametaphosphate was added for quick dispersion of soil particles. The roots were washed thoroughly under tap water and passed through a series of sieves ${ }^{9}$. Thereafter, the washed roots were scanned using a rhizo-scanner and analyzed using Winrhizo software scanner (Regent Instruments Inc., Canada). The root length density (RLD) was obtained from the following formula:

$$
\mathrm{RLD}=\frac{\text { Total root length }(\mathrm{cm})}{\text { Volume of the root sampling auger }\left(\mathrm{cm}^{3}\right)}
$$

The depth of maximum rooting was fixed up to the point until the RLD value approached $0.05 \mathrm{~cm}^{-3}$ ).

Calculation of fractional intercepted photosynthetically active radiation (fIPAR). In this experiment, line quantum sensor LI-191SA (LICOR Inc., Lin 184 coln, NE, USA) was used to measure incoming and outgoing photosynthetically active radiation (PAR) at the top as well as bottom of the canopy at 7-days interval. Fractional intercepted PAR (fIPAR) was calculated using the following formula:

$$
\mathrm{fIPAR}=\frac{\mathrm{I}_{\mathrm{o}}-\mathrm{I}_{\mathrm{t}}}{\mathrm{I}_{\mathrm{o}}}
$$

where $\mathrm{I}_{\mathrm{o}}$ and $\mathrm{I}_{\mathrm{t}}$ are incident and transmitted PAR at the top and bottom of the canopy respectively. The daily values for the whole simulation period were finally calculated by the linear interpolation method. Measured values of fIPAR at various crop growth stages in different treatments are shown in Fig. 1.

Partitioning of evaporation and transpiration component. For simulating soil moisture distribution, soil water balance and root water uptake using the Hydrus-2D model, potential maize evaporation and transpiration values were supplied to the model separately. To calculate potential crop evapotranspiration (ETc), reference evapotranspiration (ETo) is a prerequisite. Here, ETo was calculated using FAO-CROPWAT 8.0 
model $^{56}$. Etc was calculated by multiplying ETo crop coefficient. The partitioning of ETc into evaporation (Ep) and transpiration (Tp) was achieved by the following equation as described by Ritchie $^{57}$ :

$$
\mathrm{E}_{\mathrm{p}}=\mathrm{ETc} \exp (-\kappa \mathrm{LAI})
$$

where $\kappa$ is the canopy radiation extinction coefficient and LAI is leaf area index by calculating the negative slope of the relationship between $\ln (1$ - fIPAR) and LAI with intercept set to zero using the following equation":

$$
\mathrm{k}=\frac{\ln (1-\mathrm{fIPAR})}{\text { LAI }}
$$

The Hydrus-2D model. Here, the Hydrus-2D model was used to simulate the spatio-temporal variation of soil water balance components (evaporation, root water uptake, deep drainage, soil water content). The model assumes soil as a porous medium with a homogeneous isotropic structure and neglects the effect of temperature and gas on soil water movement. The governing principle behind the two-dimensional water movement in soil lies in Richard's equation ${ }^{58}$ :

$$
\frac{\partial \theta}{\partial t}=\frac{\partial}{\partial x}\left[K(h) \frac{\partial h}{\partial x}\right]+\frac{\partial}{\partial z}\left[K(h) \frac{\partial h}{\partial z}\right]+\frac{\partial k(h)}{\partial z}-S(x, z, h)
$$

where $\theta$ is the volumetric water content $\left(\mathrm{cm}^{3} \mathrm{~cm}^{-3}\right) ; h$ is the pressure head of water in the soil matrix, $K(h)$ is the unsaturated hydraulic conductivity $\left(\mathrm{cm} \mathrm{s}^{-1}\right)$ and $S(x, z, h)$ is the root water uptake sink term $\left(\mathrm{s}^{-1}\right)$. The sink term $S(x, z, h)$ for root water uptake can be described by Feddes et al. ${ }^{59}$ equation:

$$
S(\psi, x, z)=\alpha_{s}(\psi, x, z) \times b(x, z) \times T_{p} \times L
$$

where $\alpha_{\mathrm{s}}(\psi, \mathrm{x}, \mathrm{z})$ : is the dimensionless function of soil water stress, $0 \leq \mathrm{a}(\mathrm{x}, \mathrm{z}, \mathrm{h}) \leq 1 ; \mathrm{b}(\mathrm{x}, \mathrm{z})$ is the normalized root water uptake distribution function $\left(\mathrm{cm}^{-2}\right)$; W: Surface width associated with atmospheric boundary $(\mathrm{cm})$; Tp: Potential rate of transpiration $\left(\mathrm{cm} \mathrm{day}^{-1}\right)$. More detailed information on this aspect can be found from Aggarwal et al. ${ }^{23}$.

Domain geometries and discretization. Geometries depicting soil transport domain of $0-5,5-10$, $10-15$ and $15-30,30-45 \mathrm{~cm}$ soil depths are presented in Fig. 9. The model suggested default value $(2.20 \mathrm{~cm})$ was used as targeted finite element size for spatial discretization and mesh generation. The finite element size is $0.1 \mathrm{~cm}$ where emitters are located, and element size gradually increases with distance till approaches the default value. The node point of the plant base was assigned as $(0,0)$ and the coordinates of the upper boundary on the left and right side of the soil domain were kept at $(-18.75,0)$ and $(18.75,0)$ points, respectively. Similarly, the lower boundary coordinates of the left and right sides were $(-33.75,-45)$ and $(33.75,-45)$, respectively. Five observation nodes were inserted in transport domain at $(0,-2.5)(0,-7.5),(0,-12.5)(0,-22.5)$ and $(0,-37.5)$ coordinates to obtain information about spatio-temporal soil water changes. Model-derived soil water content $(\mathrm{V} / \mathrm{V})$ at these observation points were compared with volumetrically obtained soil water content (SWC) at the base of the plant (at $0-5,5-10,10-15,15-30$ and $30-45 \mathrm{~cm}$ soil depths).

Initial condition. The initial measured SWCs for all treatments at 0-5, 5-10, 10-15, 15-30 and 30-45 cm soil depths at beginning of the simulation (28th June) were taken as the input of model initial condition.

Boundary condition. The upper and lower boundary of the soil domain was assigned as atmospheric boundary and free drainage boundary, respectively. The vertical sides of the domain have no flux boundaries.

Calibration and validation. To simulate soil water distribution, root water uptake pattern, the Hydrus-2D model needs to be provided with van Genuchten-Mualem (VGM) parameters ${ }^{60}$, i.e., residual water content $(\theta \mathrm{r})$, saturated water content $(\theta s)$, saturated hydraulic conductivity $(\mathrm{Ks})$, inverse of air entry suction value $(\alpha)$, pore connectivity parameter (l), and pore size distribution index (n). Among these parameters only $\alpha, \mathrm{n}$ and $K s$ were generated using a neural network prediction program with Rosetta software package ${ }^{61}$. For these, the prediction program was supplied with soil texture and initial bulk BD inputs. The selected parameters were further optimized using the inverse optimization method (inverse solution) provided with 5 iterations. The detailed steps for optimization are described by Parihar et al. ${ }^{9}$ and Rai et al. ${ }^{62}$. In this present study total 55 data points were collected (combining 5 depth and 11 times of observation) for each treatment during the simulation period of crop growth (2019) and out of 55, 30 were used for calibration and the remaining 25 data points was used for validation. The soil moisture data (30 data points) at 1st, 8 th, $32 \mathrm{nd}, 56 \mathrm{th}$ and 64 th, $82 \mathrm{nd}$ (final) day of the simulation period were used in inverse solution for calibration of the model. For validating the accuracy of the model output, simulated values of SWC (V/V) from 5 observation nodes $(0,-2.5)(0,-7.5),(0,-12.5)(0,-22.5)$ and $(0,-37.5)$ were compared with volumetrically calculated (near the base of plants) SWC of $0-5,5-10,10-15$, 15-30, 30-45 cm soil depths.

Soil water balance. Soil water balance of the soil profile $(0-45 \mathrm{~cm})$ during the simulation period $(8-89$ DAS) was described using the following equation: 

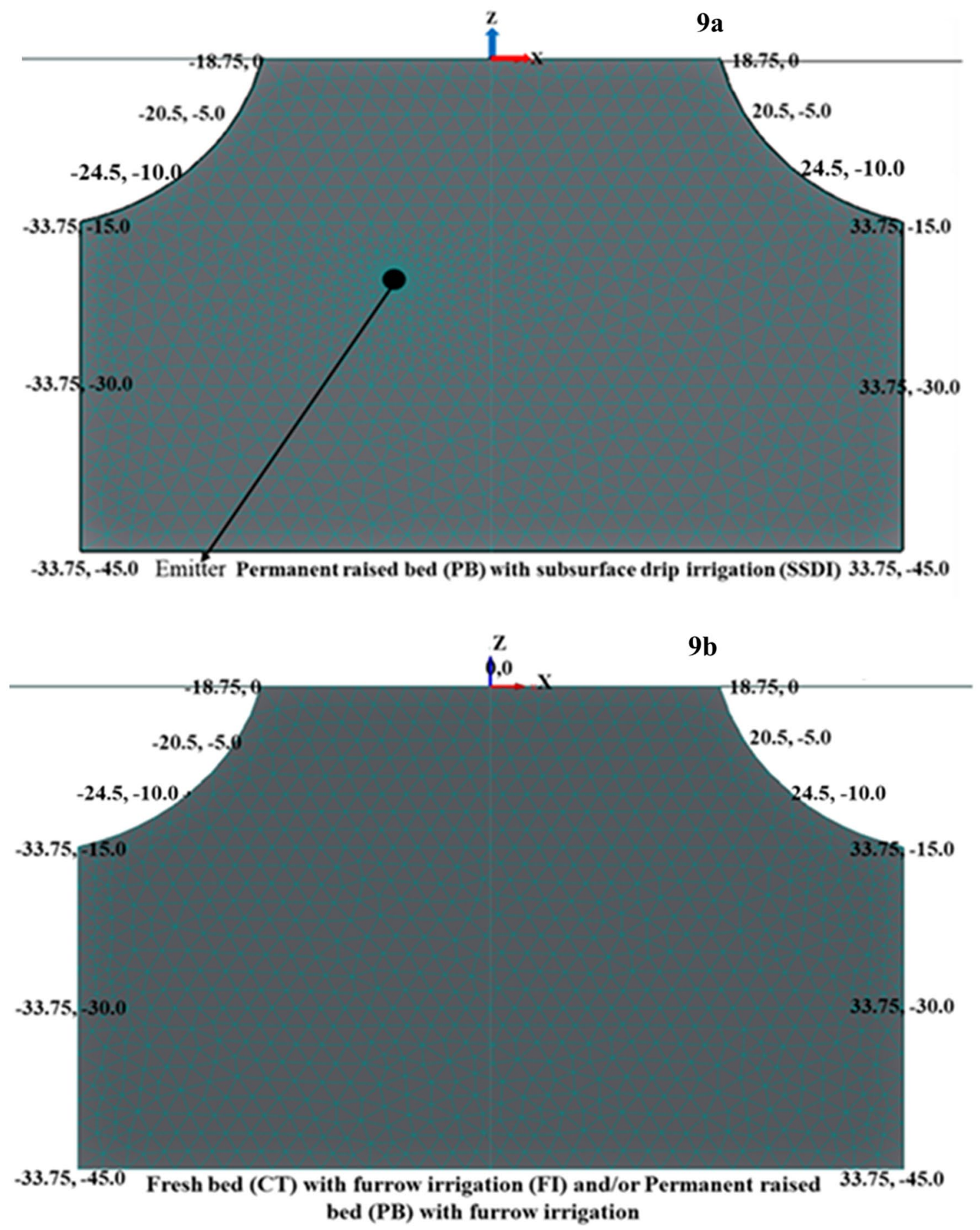

Figure 9. Geometries characterization of different land configuration.

$$
\left.S W C_{\text {initial }}+\text { Rain (or, Irrig. }\right)=S W C_{\text {final }}+\text { Cum.RWU + Cum.Evap }+ \text { Cum.Drain }
$$

where SWC initial and final: Cumulative soil water content $(\mathrm{mm})$ of $0-45 \mathrm{~cm}$ soil depth at start and end of the simulation period, respectively, Rain: Cumulative rainfall $(\mathrm{mm})$ received during simulation period, Irrig.: Total irrigation amount $(\mathrm{mm})$ applied during simulation period, Cum. RWU: Cumulative root water uptake $(\mathrm{mm})$, Cum. Evap: Cumulative surface evaporation (mm), Cum. Drain: Cumulative deep drainage (mm).

Model accuracy and performance analysis. The model accuracy and performance were evaluated under the following criteria: coefficient of determination $\left(\mathrm{R}^{2}\right)$, model efficiency (ME) and Root Mean Square Error (RMSE). The $\mathrm{R}^{2}$ describes the strength of linear regression between simulated and observed SWC. Its value ranges between 0 (no correlation) to 1 (perfect correlation). The formula for determining $\mathrm{R}^{2}$ is: 


$$
R^{2}=\frac{\left(\sum_{i}^{n}\left(O_{i}-O_{m}\right)\left(P_{i}-P_{m}\right)\right)^{2}}{\sum_{i}^{n}\left(O_{i}-O_{m}\right)^{2} \times \sum_{i}^{n}\left(P_{i}-P_{m}\right)^{2}}
$$

where Oi: Field observed moisture data and Pi: Model simulated moisture data. $O m$ and $P m$ are the mean values. The model performance in terms of accuracy was measured by model efficiency $(\mathrm{ME})^{63}$. The ME ranges between $-\infty$ to 1 . A negative value indicates the poor performance of the model while any value closer to 1 indicates better efficiency. The following formula was used to describe ME:

$$
M E=1-\frac{\left(\sum_{i}^{n}\left(O_{i}-P_{i}\right)^{2}\right.}{\left(\sum_{i}^{n}\left(O_{i}-O_{m}\right)^{2}\right.}
$$

The quantity of deviation between field observed SWC and model-simulated SWC can be described by RMSE in terms of the actual size of error and it was calculated as:

$$
R M S E=\sqrt{\frac{\sum_{i=1}^{n}\left(O_{i}-P_{i}\right)^{2}}{n}}
$$

Crop and field water productivity. Water productivity (WP) with respect to crop and field was calculated using the following formulas:

$$
\begin{gathered}
\text { Crop WP }\left(\mathrm{kg} \mathrm{ha}^{-1} \mathrm{~mm}^{-1}\right)=\frac{\text { Crop biomass accumulated upto } 89 \text { DAS }\left(\mathrm{kg} \mathrm{ha}^{-1}\right)}{\text { Root water uptake }(\mathrm{mm})+\text { Evaporation }(\mathrm{mm})} \\
W P\left(\mathrm{~kg} \mathrm{ha}^{-1} \mathrm{~mm}^{-1}\right)=\frac{\text { Crop biomass accumulated upto } 89 \text { DAS }\left(\mathrm{kg} \mathrm{ha}^{-1}\right)}{\text { Rainfall }(\mathrm{mm})+\text { Irrigation }(\mathrm{mm})}
\end{gathered}
$$

Radiation use efficiency. Daily incoming solar radiation was computed from bright sunshine hours using the Angstorm equation ${ }^{64}$. Incident PAR was obtained by multiplication of daily incoming solar radiation with a factor of 0.48. Incident PAR was multiplied with corresponding linearly interpolated fIPAR values to obtain daily intercepted PAR (IPAR). Total IPAR (TIPAR) of the simulation period was obtained through the integration of daily IPAR. Radiation use efficiency (RUE) was calculated based upon the net biomass produced during the simulation period. RUE was obtained from the slope of the linear plot between biomass yield and TIPAR.

Data analysis. The data on different parameters were subjected to the analysis of variance (ANOVA) for Randomized Block Design (RBD) ${ }^{65}$ using the general linear model procedure of the statistical analysis system (SAS Institute, Cary, NC). The differences between treatment means were performed by Fisher's least significant difference (LSD) test at $\mathrm{P}<0.05$. The calculated values of coefficient of variation from simulated soil moisture content were used to express soil moisture variability of different layers.

Received: 10 November 2020; Accepted: 28 June 2021

Published online: 18 August 2021

\section{References}

1. Ladha, J. K., Yadvinder-Singh, Erenstein, O. \& Hardy, B. Integrated Crop and Resource Management in the Rice-Wheat Systems of South Asia 69-108 (International Rice Research Institute, 2009).

2. Wang, H. et al. Straw incorporation influences soil organic carbon sequestration, greenhouse gas emission, and crop yields in a Chinese rice (Oryza sativa L.)-wheat (Triticum aestivum L.) cropping system. Soil Till. Res. 195, 104377 (2019).

3. Jiang, Y. et al. Water management to mitigate the global warming potential of rice systems: A global meta-analysis. Field Crops Res. 234, 47-54 (2019).

4. Humphreys, E. et al. Halting the groundwater decline in north-west India-which crop technologies will be winners?. Adv. Agron. 109, 156-199 (2010).

5. Yadvinder-Singh, Kukal, S. S., Jat, M. L. \& Sidhu, H. S. Improving water productivity of wheat-based cropping systems in South Asia for sustained productivity. Adv. Agron. 127, 157-258 (2014).

6. Jain, M. et al. Groundwater depletion will reduce cropping intensity in India. Sci. Adv. 7(9), eabd2849. https://doi.org/10.1126/ sciadv.abd2849 (2021).

7. Jat, M. L. et al. Conservation agriculture for sustainable intensification in South Asia. Nat. Sustain. 3(4), 336-343 (2020).

8. Chen, J., Lærke, P. E. \& Jørgensen, U. Optimized crop rotations increase biomass production without significantly changing soil carbon and nitrogen stock. Ecol. Indic. 117, 106669 (2020).

9. Parihar, C. M. et al. Soil water dynamics, water productivity and radiation use efficiency of maize under multiyear conservation agriculture during contrasting rainfall events. Field Crops Res. 241, 107570 (2019).

10. Jat, H. S. et al. Re-designing irrigated intensive cereal systems through bundling precision agronomic innovations for transitioning towards agricultural sustainability in North-West India. Sci. Rep. 9, 17929 (2019).

11. Parihar, C. M. et al. Long-term effect of conservation agriculture in maize rotations on total organic carbon, physical and biological properties of a sandy loam soil in north-western Indo-Gangetic Plains. Soil Till. Res. 161, 116-128 (2016).

12. Ayars, J. E. et al. Subsurface drip irrigation of row crops: A review of 15 years of research at the Water Management Research Laboratory. Agric. Water Manag. 42, 1-27 (1999).

13. Mohammad, A. Z. Effects of trickle irrigation system from southern Iran District Chabahar free zone. Irrigat. Drain. Syst. Eng. 4, $152(2015)$ 
14. Lamm, F. R., Stone, L. R., Manges, H. L. \& O’Brien, D. M. Optimum lateral spacing for subsurface drip-irrigated corn. Trans. ASAE 40, 1021-1027 (1997).

15. Sharda, R., Mahajan, G., Siag, M., Singh, A. \& Chauhan, B. S. Performance of drip irrigated dry-seeded rice (Oryza sativa L.) in South Asia. Paddy Water Environ. 15, 93-100 (2017).

16. Chen, R. et al. Lateral spacing in drip-irrigated wheat: The effects on soil moisture, yield, and water use efficiency. Field Crops Res. 179, 52-62 (2015).

17. Sidhu, H. S. et al. Sub-surface drip fertigation with conservation agriculture in a rice-wheat system: A breakthrough for addressing water and nitrogen use efficiency. Agric. Water Manag. 216, 273-283 (2019).

18. Hagin, J., Sneh, M. \& Lowengart-Aycicegi, A. Fertigation-fertilization through irrigation. IPI Research Topics Number 23. International Potash Institute. https://www.ipipotash.org/udocs/39-fertigation-fertilization-through-irrigation.pdf (2003).

19. Šimůnek, J., Šejna, M., Saito, H., Sakai, M. \& Van Genuchten, MTh. The HYDRUS-1D software package for simulating the movement of water, heat, and multiple solutes in variably saturated media, Version 4.0: HYDRUS Software Series 3 (Univ. of California Riverside, 2008).

20. Mermoud, A., Tamini, T. D. \& Yacouba, H. Impacts of different irrigation schedules on the water balance components of an onion crop in a semi-arid zone. Agric. Water Manag. 77, 282-295 (2005).

21. Han, M., Zhao, C., Šimůnek, J. \& Feng, G. Evaluating the impact of groundwater on cotton growth and root zone water balance using Hydrus-1D coupled with a crop growth model. Agric. Water Manag. 160, 64-75 (2015).

22. Šimůnek, J. \& Hopmans, J. W. Modeling compensated root water and nutrient uptake. Ecol. Model. 220, 505-521 (2009).

23. Aggarwal, P. et al. Modeling soil water balance and root water uptake in cotton grown under different soil conservation practices in the Indo-Gangetic Plain. Agric. Ecosyst. Environ. 240, 287-299 (2017).

24. Ahmad, M., Chakraborty, D., Aggarwal, P., Bhattacharyya, R. \& Singh, R. Modeling soil water dynamics and crop water use in a soybean-wheat rotation under chisel tillage in a sandy clay loam soil. Geoderma 327, 13-24 (2018).

25. Elnesr, M. N. \& Alazba, A. A. Simulation of water distribution under surface dripper using artificial neural networks. Comput. Electron. Agric. 143, 90-99 (2017).

26. He, Q. S., Li, S. E., Kang, S. Z., Yang, H. B. \& Qin, S. J. Simulation of water balance in a maize field under film-mulching drip irrigation. Agric. Water Manag. 210, 252-260 (2018).

27. Phogat, V., Skewes, M. A., Cox, J. W. \& Mahadevan, M. Modeling the impact of pulsing of drip irrigation on the water and salinity dynamics in soil in relation to water uptake by an almond tree. WIT Trans. Ecol. Environ. 168, 101-113 (2012).

28. Eltarabily, M. G., Bali, K. M., Negm, A. \& Yoshimura, M. C. Evaluation of root water uptake and urea fertigation distribution under subsurface drip irrigation. Water 11, 1487 (2019).

29. Provenzano, G. Using HYDRUS-2D Simulation model to evaluate wetted soil volume in subsurface drip irrigation systems. J. Irrig. Drain. Eng. 133(4), 342-349 (2007).

30. Abid, H. N. \& Abid, M. B. Predicting wetting patterns in soil from a single subsurface drip irrigation system. J. Eng. 25(9), 41-53 (2019).

31. García Morillo, J., Rodríguez Díaz, J. A., Camacho, E. \& Montesinos, P. Drip irrigation scheduling using Hydrus 2-D numerical model application for strawberry production in south-west Spain. Irrig. Drain. 66, 797-807 (2017).

32. Reyes-Esteves, R. G. \& Slack, D. C. Modeling approaches for determining appropriate depth of subsurface drip irrigation tubing in alfalfa. J. Irrig. Drain. Eng. 145(10), 04019021 (2019).

33. Elasbah, R., Selim, T., Mirdan, A. \& Berndtsson, R. Modeling of fertilizer transport for various fertigation scenarios under drip irrigation. Water 11(5), 893 (2019).

34. Hardie, M., Ridges, J., Swarts, N. \& Close, D. Drip irrigation wetting patterns and nitrate distribution: Comparison between electrical resistivity (ERI), dye tracer, and 2D soil-water modeling approaches. Irrig. Sci. 36, 97-110 (2018).

35. Rasmussen, K. J. Impact of ploughless soil tillage on yield and soil quality: A Scandinavian review. Soil Till. Res. 53, 3-14 (1999).

36. Shen, Y., McLaughlin, N., Zhang, X., Xu, M. \& Liang, A. Effect of tillage and crop residue on soil temperature following planting for a Black soil in Northeast China. Sci. Rep. 8, 4500 (2018).

37. Lal, R. Managing soil water to improve rainfed agriculture in India. J. Sustain. Agric. 32, 51-75 (2008).

38. Eberbach, P. L., Humphreys, E. \& Kukal, S. S. The effect of rice straw mulch on evapotranspiration, transpiration and soil evaporation of irrigated wheat in Punjab, India. Agric. Water Manag. 98, 1847-1855 (2011).

39. Greb, B. W. Effect of surface-applied wheat straw on soil water losses by solar distillation. Soil Sci. Soc. Am. Proc. 30, 786 (1966).

40. Evett, S. R., Colaizzi, P. D. \& Howell, T. A. Drip and evaporation. In Proceedings of the Central Plains Irrigation Conference, Sterling, CO, USA, 16-17 February 2005, pp. 33-39 (2005).

41. Patra, S. et al. Soil hydraulic response to conservation agriculture under irrigated intensive cereal-based cropping systems in a semiarid climate. Soil Till. Res. 192, 151-163 (2019).

42. Gathala, M. K. et al. Effect of tillage and crop establishment methods on physical properties of a medium textured soil under a seven-year rice-wheat rotation. Soil Sci. Soc. Am. J. 75, 1851 (2011).

43. Zegada-Lizarazu, W., Zatta, A. \& Monti, A. Water uptake efficiency and above-and belowground biomass development of sweet sorghum and maize under different water regimes. Plant Soil 351(1-2), 47-60 (2012).

44. Hillel, D. Environmental Soil Physics: Fundamentals, Applications and Environmental Considerations 1st edn, 771 (Academic Press, Waltham, 1998).

45. Norman, J. M. \& Campbell, G. S. Canopy structure. In Plant physiological ecology: Field methods and instrumentation (eds Pearcy, R. W. et al.) 301-325 (Chapman and Hall, 1989).

46. Darwish, T., Atallah, T., Hajhasan, S. \& Chranek, A. Management of nitrogen by fertigation of potato in Lebanon. Nutr. Cycl. Agroecosyst. 67, 1-11 (2003).

47. Bergamaschi, H. et al. Intercepted solar radiation by maize crops subjected to different tillage systems and water availability levels. PesqAgropec Bras 45(12), 1331-1341 (2010).

48. Parihar, C. M. et al. Conservation agriculture in irrigated intensive maize-based systems of north-western India: Effects on crop yields, water productivity and economic profitability. Field Crops Res. 193, 104-116 (2016).

49. Lindquist, J. L., Arkebauer, T. J., Walters, D. T., Cassman, K. G. \& Dobermann, A. Maize radiation use efficiency under optimal growth conditions. Agron. J. Am. Soc. Agron. 97, 72-78 (2005).

50. Lamm, F. R. \& Trooien, T. P. Subsurface drip irrigation for corn production: A review of 10 years of research in Kansas. Irrig. Sci. 22, 195-200 (2003).

51. Ajaz, A., Datta, S. \& Stoodley, S. High plains aquifer-state of affairs of irrigated agriculture and role of irrigation in the sustainability paradigm. Sustainability 12, $3714(2020)$.

52. Sharma, A. R. \& Dass, A. Maize. In Textbook of Field Crops Production-Food Grain Crops Vol. 1 (ed. Prasad, R.) 120 (ICAR, 2002).

53. Klute, A. Water retention: Laboratory methods. In Methods of Soil Analysis, Part 1-Physical and Mineralogical Methods, SSSA Book Ser. 5.1 (ed. Klute, A.) 663-686 (SSSA, ASA, 1986).

54. Bouyoucos, G. J. Hydrometer method improved for making particle size analysis of soil. Agron. J. 54, 464-465 (1962).

55. Aggarwal, P., Choudhary, K. K., Singh, A. K. \& Chakraborty, D. Variation in soil strength and rooting characteristics of wheat in relation to soil management. Geoderma 136, 353-363 (2006).

56. FAO. CROPWAT-A computer program for irrigation planning and management. In FAO Irrigation and Drainage Paper No. 46 126 (FAO, 1992). 
57. Ritchie, J. T. Model for predicting evaporation from a row crop with incomplete cover. Water Resour. Res. 8, 1204-1213 (1972).

58. Šimůnek, J., van Genuchten, M. T. \& Šejna, M. The HYDRUS Software Package for Simulating Two and Three-Dimensional Movement of Water, Heat, and Multiple Solutes in Variably-Saturated Media. Technical Manual, Version 2. PC Progress (2011).

59. Feddes, R. A., Kowalik, P. J. \& Zaradny, H. Simulation of field water use and crop yield. Soil Sci. 129, 193 (1982).

60. van Genuchten, MTh. A closed form equation for predicting the hydraulic conductivity of unsaturated soils. Soil Sci. Soc. Am. J. 44, 892-898 (1980).

61. Schaap, M. G., Feike, J. L. \& van Genuchten, M. T. ROSETTA: A computer program for estimating soil hydraulic parameters with hierarchical pedo-transfer functions. J. Hydrol. 251, 163-176 (2001).

62. Rai, V. et al. Modeling soil hydrothermal regimes in pigeon pea under conservation agriculture using Hydrus-2D. Soil Till. Res. 190, 92-108 (2019).

63. Nash, J. E. \& Sutcliffe, J. V. River flow forecasting through conceptual models' part I-A discussion of principles. J. Hydrol. 10, 282-290 (1970).

64. Allen, R. G., Pereira, L. S., Raes, D. \& Smith, M. Crop Evapotranspiration: Guidelines for Computing Crop Water Requirements. Irrigation and Drainage Paper No.56. 300 (FAO, 1998).

65. Gomez, K. A. \& Gomez, A. A. Statistical Procedures for Agricultural Research 187-215 (Wiley, 1984).

\title{
Acknowledgements
}

We sincerely acknowledge Indian Council of Agricultural Research (ICAR), ICAR-Indian Agricultural Research Institute (IARI), for providing the scholarship and other facilities. The research was conducted at CIMMYTBISA Farm, Ludhiana, India and supported by Indian Council of Agricultural Research (ICAR) Window 3 grant to CIMMYT, CGIAR Research programs on Climate Change, Agriculture and Food Security (CCAFS) and Wheat Agri-Food Systems through CIMMYT Academy. The support received from Divisions of Agronomy, Plant Physiology, Agricultural Physics, and Soil Science \& Agricultural Chemistry of ICAR-IARI, New Delhi and ICAR-Indian Institute of Maize Research (IIMR) is also acknowledged. Special thanks to Dr. D.K. Singh, Professor, ICAR-IARI, Dr. P. Krishnan, Head, ICAR-IARI, Dr.Renu Pandey, Pr. Scientist, ICAR-IARI, Dr. V.K. Sharma, Pr. Scientist, ICAR-IARI, Dr. B.N. Mandal, Sr. Scientist, ICAR-IASRI, Dr. P. Aggarwal, Ex-Pr. Scientist, ICAR-IARI, Dr. A. Sarangi, Pr. Scientist, ICAR-IARI, WTC, and Dr. Yadvinder-Singh, Dr. Naveen Gupta, Dr. K.M Choudhary, Mr. Sanjeev, Mr. Kashmiri of CIMMYT-BISA, and Mr. Sanjeev Kumar of ICAR-IIMR for assistance in data management and analysis work. Permissions statement: This study was conducted under the agreement between CIMMYT Academy (BISA-CIMMYT) and IARI duly signed and approved by the authorities of the respective institution/organization and also included the authorship from all the institutions as per their contribution.

\section{Author contributions}

K.P., C.M.P., H.S.N., B.R., M.D.P. and L.K.S. participated in conducting the research, data analysis and writing of the manuscript; M.L. and B.G. conceptualized the research and contributed to revision of the manuscript and funding acquisition; H.S. Sidhu participated in designing of subsurface drip irrigation; V.K.S., S.L. and S.P. participated research design, editing and revision of the manuscript.

\section{Competing interests}

The authors declare no competing interests.

\section{Additional information}

Correspondence and requests for materials should be addressed to C.M.P. or M.L.J.

Reprints and permissions information is available at www.nature.com/reprints.

Publisher's note Springer Nature remains neutral with regard to jurisdictional claims in published maps and institutional affiliations.

\begin{abstract}
Open Access This article is licensed under a Creative Commons Attribution 4.0 International License, which permits use, sharing, adaptation, distribution and reproduction in any medium or format, as long as you give appropriate credit to the original author(s) and the source, provide a link to the Creative Commons licence, and indicate if changes were made. The images or other third party material in this article are included in the article's Creative Commons licence, unless indicated otherwise in a credit line to the material. If material is not included in the article's Creative Commons licence and your intended use is not permitted by statutory regulation or exceeds the permitted use, you will need to obtain permission directly from the copyright holder. To view a copy of this licence, visit http://creativecommons.org/licenses/by/4.0/.
\end{abstract}

(C) The Author(s) 2021 